ISSN: 2051-0861

Publication details, including guidelines for submissions:

https://journals.le.ac.uk/ojs1/index.php/nmes

\title{
Geopolitical Challenges, Complexities, and Future Uncertainties in the Occupied Palestinian Territories: Land and Population's Perspectives
}

Author(s): Hilmi S. Salem

To cite this article: Salem, Hilmi S. (2020) "Geopolitical Challenges, Complexities, and Future Uncertainties in the Occupied Palestinian Territories: Land and Population's Perspectives", New Middle Eastern Studies 10 (1), pp. 45-82.

Online Publication Date: 2 October 2020

\section{Disclaimer and Copyright}

The NMES editors make every effort to ensure the accuracy of all the information contained in the journal. However, the Editors and the University of Leicester make no representations or warranties whatsoever as to the accuracy, completeness or suitability for any purpose of the content and disclaim all such representations and warranties whether express or implied to the maximum extent permitted by law. Any views expressed in this publication are the views of the Author and not the views of the Editors or the University of Leicester.

Copyright New Middle Eastern Studies, 2020. All rights reserved. No part of this publication may be reproduced, stored, transmitted or disseminated, in any form, or by any means, without prior written permission from New Middle Eastern Studies, to whom all requests to reproduce copyright material should be directed, in writing.

\section{Terms and Conditions}

This article may be used for research, teaching and private study purposes. Any substantial or systematic reproduction, re-distribution, re-selling, loan or sub-licensing, systematic supply or distribution in any form to anyone is expressly forbidden.

The publisher does not give any warranty express or implied or make any representation that the contents will be complete or accurate or up to date. The accuracy of any instructions, formulae and drug doses should be independently verified with primary sources. The publisher shall not be liable for any loss, actions, claims, proceedings, demand or costs or damages whatsoever or howsoever caused arising directly or indirectly in connection with or arising out of the use of this material. 


\title{
Geopolitical Challenges, Complexities, and Future Uncertainties in the Occupied Palestinian Territories: Land and Population's Perspectives
}

\author{
Hilmi S. Salem*
}

\begin{abstract}
Geopolitical challenges, complexities, and future uncertainties have greatly and adversely affected all aspects of life, as well as the well-being of the Palestinian citizens living in the Occupied Palestinian Territories (OPT), comprised of the West Bank, including East Jerusalem, and the Gaza Strip. The OPT were militarily occupied by the Israeli forces in June 1967 and, since then, the Israeli military rules have been applied to the OPT. The demographic issues in the OPT have gained a great importance at the political, geopolitical, social, economic, environmental, educational, health-wise, and housing, as well as at other aspects of life. This is due to the fact that demographic issues, along with the land, are the main determinants of the Palestinian choices towards sustainable development in a future, sovereign, independent, stable, and secure state of Palestine to be established in the OPT, with East Jerusalem as its capital. So, because of the limited areas of land which Palestinians have access to; because of the limited natural resources that are available to them; and because of the narrowing of the political horizons and choices available to the Palestinians, the real Palestinian wealth in the OPT is the human being. This article investigates and analyses several geopolitical challenges, complexities, and future uncertainties in the OPT, with a focus on key demographic issues, including human trends and socioeconomic trends, which include marital status, housing, education, and health. Additionally, the article examines the historical background of the present situation. It also provides important recommendations and supporting elements towards developing Palestinian national policies related to the well-being of the Palestinian citizens and institutions within the OPT.
\end{abstract}

Keywords: Occupied Palestinian Territories (OPT: West Bank, East Jerusalem, and Gaza Strip); Oslo Agreement, Area A, Area B, and Area $C$; Israeli Military Occupation; Israeli Settlements and Israeli Segregation Wall; Population and Socioeconomic Elements: Marital Status, Housing, Education, and Health; Geopolitical Challenges, Complexities, and Future Uncertainties.

\section{Introduction}

The Palestinian people have been continuously struggling and deeply suffering for more than 72 years now, i.e. since their home-country - Historical Palestine - was militarily taken away from them by the Zionist Movement in May 1948. As a result, the state of Israel was

*Hilmi S. Salem, Professor Doctor, Sustainable Development Research Institute, Bethlehem, West Bank, Palestine (Occupied). Email: hilmisalem@yahoo.com 
established in Historical Palestine at the expense of the native population of the country - the Palestinian people. Also, more than 720,000 Palestinians hitherto (until May 1948) living in Historical Palestine were evicted and driven out of their homes to the West Bank and the Gaza Strip (within Historical Palestine); to the neighbouring Arab countries (mostly to Jordan, Syria, and Lebanon); and to other countries throughout the world. Additional Palestinians were displaced from their homes but stayed within the 1948 Israeli-controlled territories. The Israelis controlled 774 cities, towns, and villages, and they destroyed and ethnically cleansed 531 Palestinian towns and villages in 1948 (PCBS 2016a). The issue of the Palestinian refugees became known, since May 1948, as the Palestinian "Nakba" (Catastrophe), representing and symbolizing the endless suffering of the Palestinian refugees. Those refugees and their descendants are now more than six million, living in Historical Palestine and throughout the world. The Palestinian people, in total, are now approximately 13 million, living in Historical Palestine and constituting the Diaspora, of which around 6.5 million live within Historical Palestine and the other 6.5 million live abroad.

After the Six-Day War in June 1967, the Israeli forces occupied the remaining parts of Historical Palestine (i.e. the West Bank, including East Jerusalem, and the Gaza Strip), and thus, all of Historical Palestine fell under the Israeli control (Figure 1).

Figure 1: Left: Map of Historical Palestine, showing the loss of the Palestinian land to the Zionist state 'Israel' since 1946 until 2010 and ongoing (Wikipedia 2014); Middle: Map of Historical Palestine, showing the 'State of Israel' (established in 1948) and the territories occupied by Israel in 1967 (the Gaza Strip and the West Bank (including East Jerusalem)) (Salem et al. 2007); and Right: The West Bank's land division into 'Area A', 'Area B', and 'Area C', according to the Oslo Agreement signed in 1993/1995 between the Palestine Liberation Organization (PLO) and the State of Israel (Wikipedia 2011).

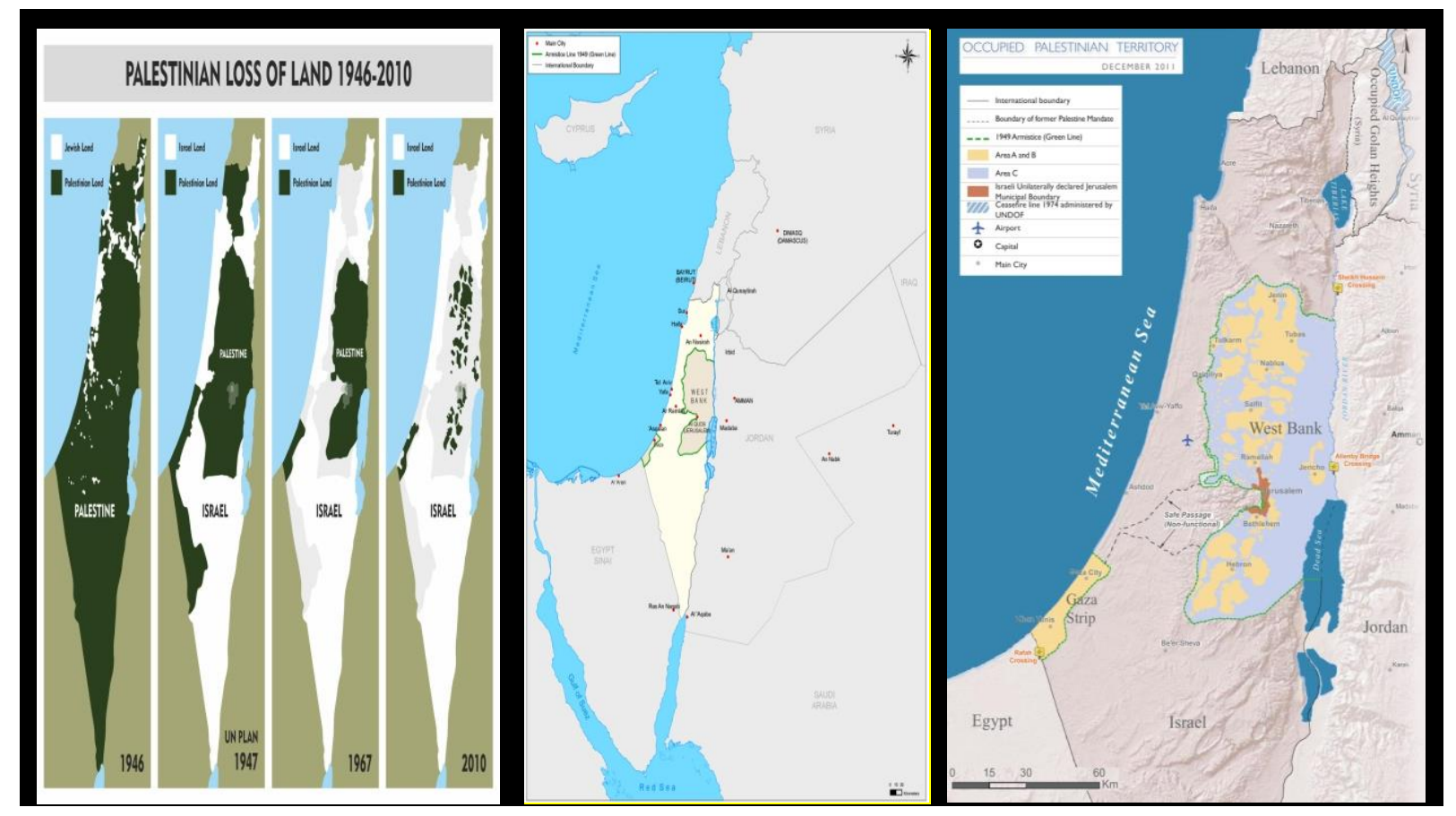


Since then, the 1967-occupied territories have been known, according to United Nations' (UN) resolutions, as the "Occupied Palestinian Territories" (OPT). On the $29^{\text {th }}$ of November 2012, the UN's General Assembly recognized the OPT as the "State of Palestine with East Jerusalem as its Capital", being under the Israeli occupation. Constituting 22\% of Historical Palestine (Figure 1-Right), the 1967-OPT have a total area of $6,031 \mathrm{~km}^{2}$, including the Gaza Strip (with an area of $360 \mathrm{~km}^{2}$ ) and the West Bank, including East Jerusalem (with an area of $\left.5,671 \mathrm{~km}^{2}\right)$.

An extensive scholarly literature is now available on the "Question of Palestine". That literature deals with several issues, including, for example, Historical Palestine; the History of Palestine; Zionism; the Palestinian refugees and their "Nakba" (Catastrophe); the state of Israel; the 1967 War and its resultant - the Occupation of the Palestinian Territories (the West Bank, East Jerusalem, and Gaza Strip); the United Nations Resolutions related to the Question of Palestine; the Jewish settlements in the West Bank; the Israeli Segregation Wall; the Israeli military rules applied to the OPT; the Oslo Agreement and its resultant - the division of the occupied West Bank into Area A, Area B, and Area C; population; socioeconomic development programs; natural resources, the Israeli blockade on the Gaza Strip since 2007; and many others.

For example, Zayid (1980) and Mayamey (2010) investigated Zionism as an ideology focused on the establishment of a Jewish national home in Palestine. The Zionist Movement started as an ideology with Theodor Herzl (1860-1904; the founder of Political Zionism) in the late $19^{\text {th }}$ century and moved forward to its manifestation represented in the establishment of the state of Israel, which started with David Ben-Gurion (1886-1973; the first Prime Minister of the state of Israel in 1948). Ilan Pappé (Jewish-Israeli historian) refers in his studies, regarding the Palestine Question, to what is known as the "Plan Delat" (sometimes written as "Plan Dalet"), which was the military strategy adopted by the Jewish forces that outlined the destruction of Arab villages in areas awarded to the state of Israel and beyond. Pappé considers "Plan Delat" as the "design" for the Palestinian exodus, as he states, " $A$ master plan for the expulsion of as many Palestinians as possible” (Pappé 1992). Masalha (1992) pointed out that, "The concept of transfer [adopted by Israeli leaders] lies at the very heart of mainstream Zionism." Zayid (2002a) and Pappé (2006a; 2006b) affirmed that what happened to the Palestinians in 1948 in Historical Palestine was "Ethnic Cleansing", resulting in the evacuation of hundreds of thousands of Palestinians from their homes and lands, who, since then, became refugees, and Israel is not allowing them to go back to their homes and lands.

The United Nations' (UN) General Assembly has adopted, immediately, after the Palestinian "Nakba" the Resolution 194, resolving that:

Refugees wishing to return to their homes and live at peace with their neighbours should be permitted to do so at the earliest practicable date, and that compensation should be paid for the property of those choosing not to return and for loss of or damage to property which, under principles of international law or equity, should be made good by the governments or authorities responsible (UNRWA 1950).

UNRWA affirms that: 
Palestinian refugees, both first-generation refugees who are still alive and their descendants have a right to return, and a right to the property they themselves or their forebears left behind or were forced to leave in what is now Israel and the Palestinian territories (both formerly part of the British Mandate of Palestine), as part of the 1948 Palestinian exodus, a result of the 1948 Palestine war, and due to the 1967 Six-Day War (Wikipedia 2020a). ${ }^{1}$

In this study, several of the above-mentioned issues are investigated and analysed, and in the end of the study more than 20 recommendations are reached and provided.

\section{Historical Background}

During its brief imperium (1917-1948) in Historical Palestine, Britain kept the promise made on 2 November 1917 by its Foreign Secretary Arthur James Balfour (1848-1930), in the Declaration that bears his name, "To favour the establishment in Palestine of a national home for the Jewish people" (Zayid 2002a). According to the "Balfour Declaration", the state of Israel was founded in 1948 on the ruins of the Palestinian communities and at the expense of the Palestinian people and their suffering.

Until 1948, 1.4 million Palestinians lived in around 1,300 Palestinian cities, towns, and villages throughout Historical Palestine, with a total area of 27,000 km². Before 1948 (19391947), violent military actions, including massacres against innocent Palestinian civilians, were carried out by the Zionist paramilitary groups (i.e. the Irgun, Lehi, Haganah, and Palmach) to control Palestine, and replace its indigenous Arab population with Jewish Zionists, who migrated to Historical Palestine from Europe and other parts of the world, with the support of the British Government, which controlled Historical Palestine at the time (Zayid 2002b; Zayid 2006; Salem 2009). In his Doctoral Dissertation carried out at the Oxford University, Hoffman (1985) examined the influence that Jewish terrorist activities had on Britain's policy for Palestine, and he ascertained the role played by Jewish Zionist terrorists in that decision.

It is important to mention that Jewish Zionist terrorism was strongly practiced against, not only the native Palestinian population of the land, but also against the British authorities (soldiers and officials) and even against the United Nations' officials. For example, the King David Hotel's bombing was a terrorist attack carried out on 22 July 1946, by the militant right-wing Zionist underground organization - Irgun - on the British Administrative Headquarters for Palestine, which was housed in the southern wing of the King David Hotel in Jerusalem, Palestine. As a result, 91 people of various nationalities were killed, and 46 were injured (Clarke 1981). On 17 September 1948, Mr. Folke Bernadotte (1895-1948; the United Nations' Security Council's Mediator in the Arab-Israeli conflict of 1947-1948) was assassinated in Jerusalem, Palestine, by the militant Zionist group - Lehi - (commonly known as the Stern Gang or Stern Group) while pursuing his official duties (Neff 1995).

The British army occupied Historical Palestine since December 1917 until its withdrawal from it on 14 May 1948, which led to the establishment of the state of Israel in Historical Palestine on 15 May 1948. Without Great Britain, there would not have been an 
Israel for the "Yishuv", and would not be a "Nakba" (Catastrophe) for Palestine's Arab majority in Historical Palestine (Glass 2001). Tom Segev (a Jewish-Israeli historian) pointed out that the British army, as it withdrew from Palestine in May 1948, was careful to hand over its main military bases to the Zionist forces even as it attempted to protect Jaffa's Arabs from eviction (Glass 2001). The Jewish residents and Jewish new settlers in Historical Palestine were referred to collectively as the "Yishuv". The term Yishuv came into use in the 1880s, when there were a few thousands of Jewish people living in Historical Palestine. The term continued to be used until 1948, by which time there were about 700,000 Jews in Palestine, who forcefully replaced more than 720,000 native Palestinian citizens, out of the 900,000 who lived until 1948 in Palestine which became "Israel". Those Palestinians fled or were expelled from their homes, which resulted in what is known, since May 1948, as the Palestinian Nakba, as indicated above.

The forceful exodus of native Palestinians from their home-country is referred to by the Israelis as the "Collective Transfer", while the Palestinians refer to it as "Ethnic Cleansing". The causes of this exodus are controversial and debated by historians. However, Ilan Pappé (a Jewish-Israeli historian and presently professor at the College of Social Sciences and International Studies, University of Exeter in the United Kingdom) wrote, in his own words, "I want to make the case for the paradigm of ethnic cleansing and use it to replace the paradigm of war as the basis for the scholarly research of, and public debate about, 1948" (Pappé 2006a: 19, online copy).

The 1948 Palestinian exodus resulted from a planned ethnic cleansing of Palestine was implemented by the Zionist Movement's leaders, mainly David Ben-Gurion (the first Israeli Prime Minister) and the other ten members of his "Consultancy Group" (Pappé 2006a; 2006b). Pappé (2006a; 2006b) argues that the ethnic cleansing was put into effect through systematic expulsions of about 500 Arab villages, as well as terrorist attacks executed mainly by members of the Irgun and Haganah troops against the civilian population. In his research, Pappé $(2006 \mathrm{a} ; 2006 \mathrm{~b})$ refers to the aforementioned "Plan Dalet" and to the files of the villages, which were ethnically cleansed by Zionist gangs, as a proof of the planned expulsions.

In this regard, it is worth mentioning that thousands of Jewish and non-Jewish scientists, intellectuals, Noble-Price laureates, etc., as well as international organizations have never agreed with the Zionist Project of the establishment of the state of Israel in Historical Palestine, and/or Israel's inhumane treatment of the Palestinians, Israel's Apartheid system, Ethnic Cleansing, injustices inflected on the Palestinian people, etc. Among these are, just to mention a few, Albert Einstein, Sigmund Freud, Isaac Asimov, Sir Edwin Montagu, Hannah Arendt, Israel Shahak, Ilan Pappé, Richard Falk, Uri Avnery, Noam Chomsky, Norman Finkelstein, Henry Siegman, Elmer Berger, Judge Richard Goldstone, Jeff Halper, and many others. A more detailed list of the names of such distinguished personalities and organizations is provided by The HyperTexts (2010). 


\section{The Occupied Palestinian Territories and the Oslo Agreement}

In 1993/1995, the Oslo Agreement (also known as the Oslo Accords) was signed between the state of Israel and the Palestinian leadership, represented by the Palestine Liberation Organization (PLO). During the Israeli-Palestinian negotiations which took place in Oslo, Norway, a first-step agreement was reached by both sides, in which Israel agreed to withdraw its military forces from certain Palestinian areas, including parts of the West Bank and the Gaza Strip. Based on the Oslo Agreement, the West Bank was divided into three areas, along with the "Nature Reserves" region (Salem 2011; Salem 2019a; Wikipedia 2020b) (Figure 1Right; Table 1), as explained below.

- Area A: This area, comprising about $18 \%$ of the West Bank's territory, includes all Palestinian cities and the majority of the Palestinian population. In this area, which was initially amounted to $3 \%$ of the land of the West Bank and was extended in 2006 to cover $17.8 \%(\approx 18 \%)$ of the West Bank's territory, the Palestinian Authority has full control in terms of civil administration and security. The Palestinian population in this area was about 1,140,000 inhabitants in 2006, forming about $46.6 \%$ of the total population of the West Bank. Presently the population of "Area A" forms approximately 55\% of the West Bank's total population (Table 1).

- Area B: This area, comprising approximately $19 \%$ of the West Bank's territory, encompasses small towns and villages in rural areas of the West Bank. It is under the Palestinian control in terms of civil administration, and under the Israeli control in terms of security. In the year 2000, this area covered about $18.3 \%$ of the West Bank's territory. In 2006, the population in this area was about 905,000 inhabitants, forming about $37 \%$ of the total population in the West Bank. Presently, the population in this area is around $41 \%$ of the total population of the West Bank (Table 1).

- Area $C$ : This area, covering approximately $60 \%$ of the West Bank's territory, is the only area that is contiguous, engulfing the fragmented islands of Area A and Area B. This area, since the signing of the Oslo Agreement in 1993/1995, is still fully under the Israeli control, in terms of civil administration and security. In the year 2000, this area covered about $64.5 \%$ of the West Bank's territory. In 2006, the population in this area was about 397,000 inhabitants, forming about $16.3 \%$ of the total population in the West Bank. Presently, the Palestinian population in this area is only about $4 \%$ of the West Bank's total population (Table 1). According to the Oslo Agreement, "Area $C$ " is defined as follows: "Area C means areas of the West Bank outside the Area A and Area B, which, except for the issues that will be negotiated in the permanent status negotiations, will be gradually transferred to Palestinian jurisdiction in accordance with this Agreement" (TWIP 2015). The issues that will be negotiated in relation to the OPT, according to Article XVII of the Oslo Agreement, are: Jerusalem, the Jewish settlements, specified military locations, the Palestinian refugees, water, the borders, and foreign relations. Parts of Area $C$ are military zones closed to Palestinians. The Oslo Interim Agreement signed in 1995 states that East Jerusalem was not classified as Area A, Area B, or Area C and, thus, its status is to be resolved in the final status negotiations (The World Bank 2008). 
- The Nature Reserves: These are set aside for the purpose of preserving some fauna and flora and dedicated to the protection and maintenance of biodiversity, as well as natural and cultural resources. These reserves presently form about 3\% of the West Bank's territory, and the predominantly Bedouin's population on these reserves is about $0.1 \%$ of the total population of the West Bank (Table 1).

Table 1: Dividing the occupied West Bank into three areas (Area A, Area B, and Area C) and Nature Reserves, according to the Oslo Agreement signed in 1993/1995 (Salem 2011).

\begin{tabular}{|c|c|c|c|c|}
\hline Area & Security & $\begin{array}{c}\text { Civil } \\
\text { Administration }\end{array}$ & $\begin{array}{c}\% \text { of the } \\
\text { West Bank's } \\
\text { Territory }\end{array}$ & $\begin{array}{c}\% \text { of the } \\
\text { West Bank's } \\
\text { Population }\end{array}$ \\
\hline "A" & Palestinian & Palestinian & $\approx 18$ & 55 \\
\hline "B" & Israeli & Palestinian & $\approx 19$ & 41 \\
\hline "C" & Israeli & Israeli & $\approx 60$ & 4 \\
\hline \hline Nature Reserves & & & 3 & $\approx 0.1$ \\
\hline
\end{tabular}

The division of the occupied West Bank's territory into Area A, Area B, and Area C indicates that Area $A$ has the lowest percentage of area and the highest percentage of population (Table 1), resulting in the highest population density among the three areas $(A, B$, and $C$ ). Meanwhile, Area $C$ has the highest percentage of area and the lowest percentage of population (Table 1), resulting in the lowest population density among the three areas. The Palestinian citizens who own lands in Area $C$ are prohibited from reaching and developing them. The geopolitical division of the occupied West Bank into the three areas $(A, B$, and $C)$ has very badly influenced the demographic distribution and all the Palestinian development plans and strategies, as well as the daily life of the Palestinians and their activities related to economy, healthcare, education, agriculture, water, energy, construction, infrastructure, environment, natural resources, industry, trade, etc.

It is no exaggeration if one says that the Oslo Agreement's division of the West Bank intro the three areas $(A, B$, and $C$ ) with different jurisdiction has totally paralyzed the life of the Palestinian citizens living in the occupied West Bank, including East Jerusalem. Also, according to the Oslo Agreement, the occupied East Jerusalem and the besieged (occupied) Gaza Strip have become totally isolated from the occupied West Bank, and the West Bank and the Gaza Strip have also become totally isolated from the territory behind the Green Line (Israeli proper). Therefore, Palestinian citizens need Israeli permits to move from one territory to another, which are not easy to obtain. It is worth mentioning that despite the fact that 27 years have passed since the singing of the Oslo Agreement in 1993, the entire West Bank, with its three areas $(A, B$, and $C)$, is still entirely under the total control of the Israeli military, security-wise and administration-wise. Overall, the West Bank's division into the above three areas has made life much worse for the Palestinian people living in the OPT than it was 27 years ago (i.e. before the signing of the Oslo Agreement in 1993). 


\section{The Israeli Colonies and the Israeli Segregation (Apartheid) Wall in the Occupied Palestinian Territories}

Since Israel's military forces occupied the West Bank and the Gaza Strip in June 1967, Israel has never stopped its illegal actions, including building hundreds of settlements (colonies forJews-only) (Figure 2) and the construction of the Israeli Segregation (Apartheid) Wall (ISW) (known by the Israelis as the "Separation Wall"), which is surrounding the occupied West Bank, with a total length of more than $700 \mathrm{~km}$ and a height, in some locations, of more than $12 \mathrm{~m}$ (Figure 3), using highly advanced technologies for security (Salem 2011; Abdallah and Swaileh 2011; Isaac et al. 2015).

Figure 2: Map showing the growth of the Israeli settlements in the Occupied West Bank (after Williams and Zarracina 2016).

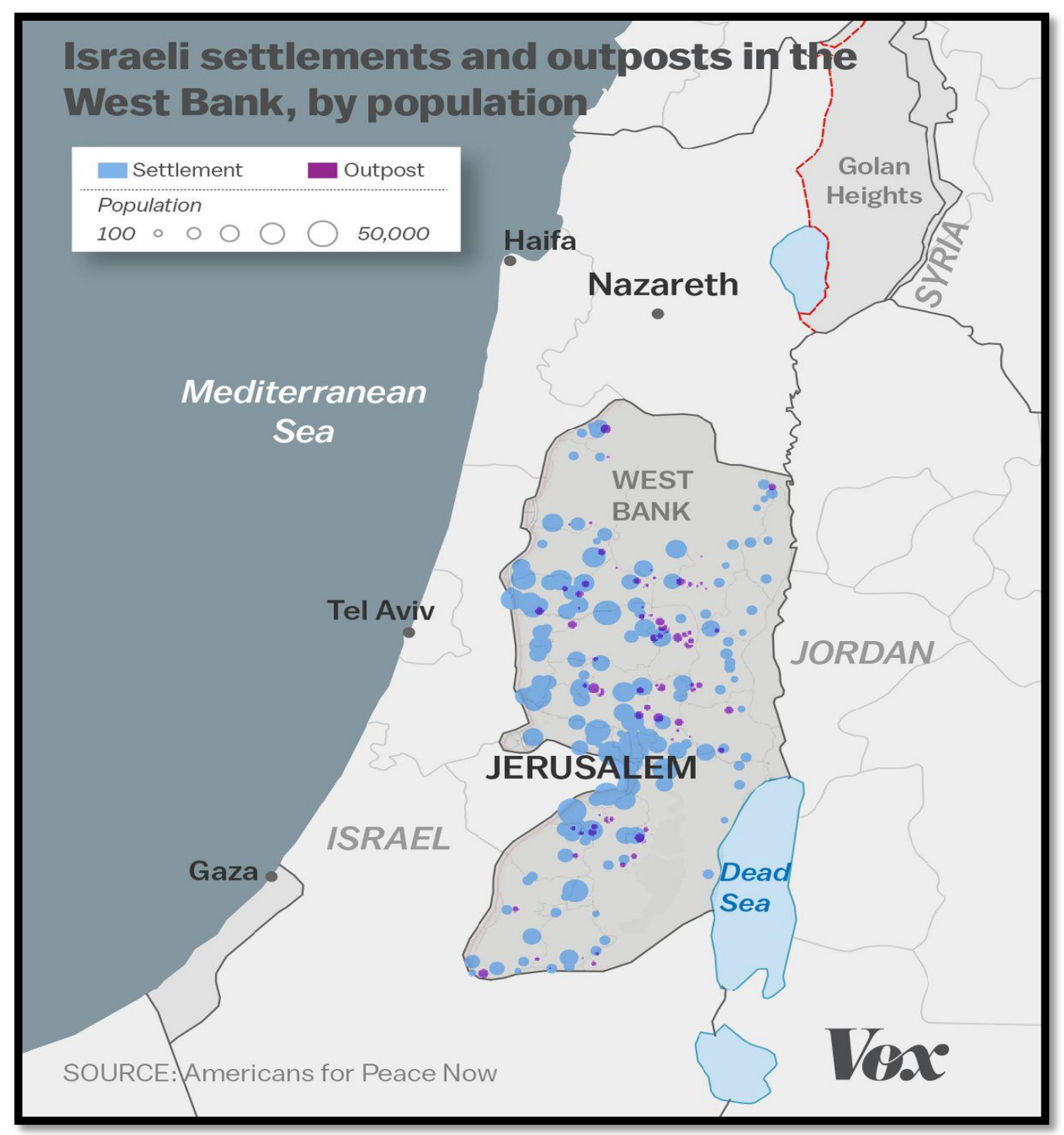

The incessant building of Israeli colonies in the occupied West Bank constitutes the biggest obstacle for peace between the Palestinians and the Israelis. Regarding the Israeli colonies in the Gaza Strip, the Knesset (Israeli Parliament) approved in February 2005 a 
unilateral disengagement plan and began removing the Israeli settlers from the Gaza Strip in 2005. All of the 21 Israeli colonies in the Gaza Strip were dismantled, and approximately 9,000 Jewish settlers, most of whom were living in the Gush Katif colony, were evicted. Some Jewish settlers still think to return back to the previous settlements in the Gaza Strip which were dismantled in 2005 (Shalom and Ben Kimon 2016).

Figure 3: Three pictures of the Israeli Segregation (Apartheid) Wall (ISW), surrounding the occupied West Bank. Left: The ISW dividing a Palestinian community (Provéndol 2012); Middle: Young Palestinians climbing the ISW to attend prayers at Al-Aqsa Mosque, Occupied Jerusalem, 26 July 2013 (Zonszein 2014); Right: The Pope Francis standing in front of the ISW during his visit to the City of Bethlehem, OPT in May 2014 (Vick 2014).

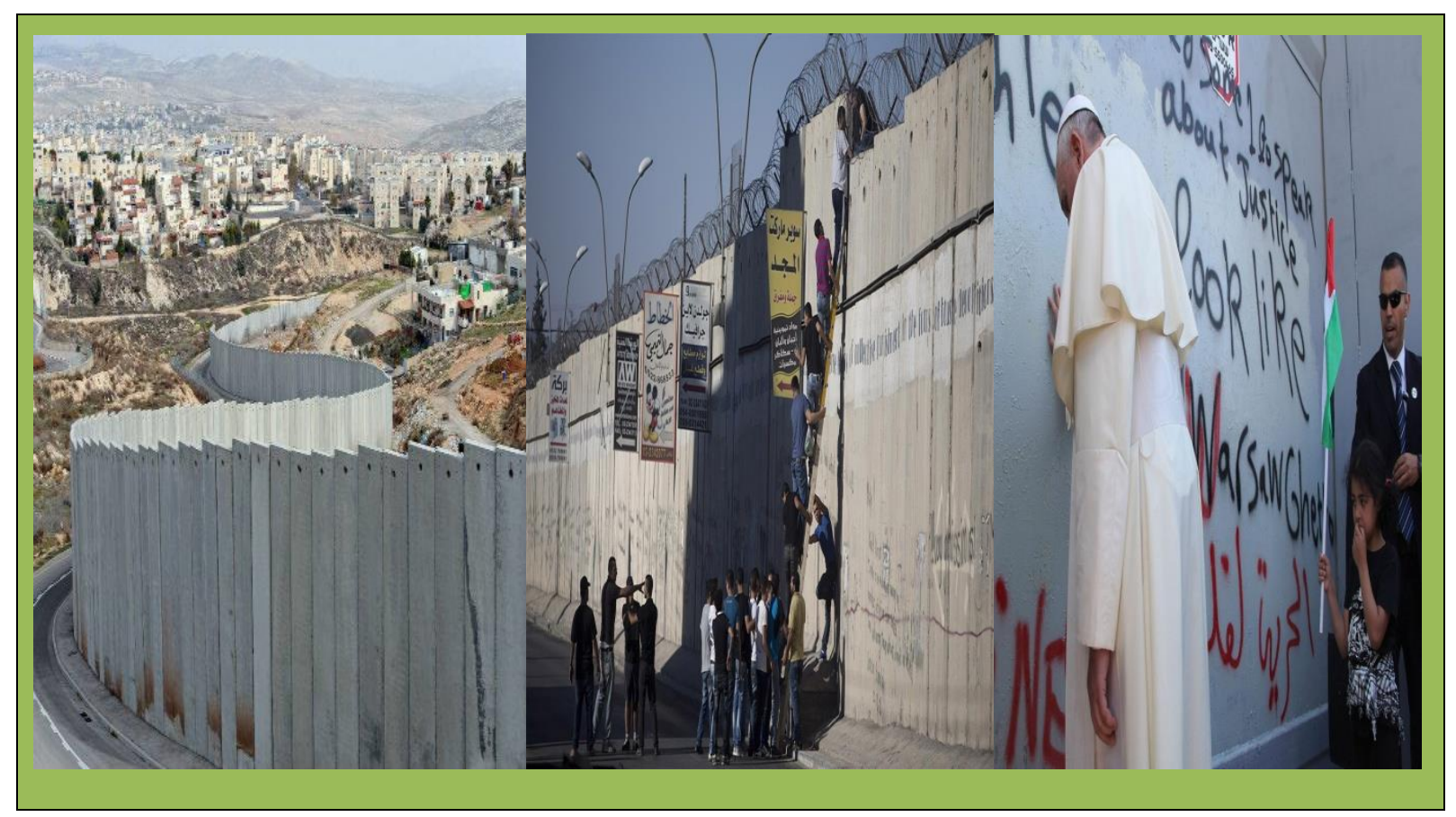

\section{The Palestinian and Israeli Population}

The Palestinian Central Bureau of Statistics (PCBS) conducted its first census in the OPT (West Bank and Gaza Strip) in 1997 (PCBS 1999). This census showed that total Palestinian population of the OPT was about 2.9 million inhabitants, of which about 1.9 million in the West Bank (including East Jerusalem) and about one million in the Gaza Strip. By the end of 2016, the number of Palestinians in the world was 12.73 million, of whom 4.9 million live in the OPT (including 2.9 million in the West Bank (including East Jerusalem), and 2 million in the Gaza Strip); 1.53 million in Israel (meaning, 6.43 million in Historical Palestine); 5.6 million in Arab countries; and around 0.7 million in foreign countries (meaning, 6.3 million in Diaspora). The Palestinian refugees comprise $42 \%$ of the Palestinian population in the OPT, whereby more than two-thirds of them live in the Gaza Strip and the rest in the West Bank (PCBS 2016b). By the beginning of 2017, the total population of Palestinians, worldwide, reached 12.706 million, distributed as follows: $23.4 \%$ in the West Bank, $15 \%$ in 
the Gaza Strip, 12.1\% in Israel (within the 1948-Green Line), 44\% in Arab countries, and $5.5 \%$ in other countries throughout the world (AZC 2017). These figures indicate that currently around $50 \%$ of the total Palestinians, worldwide, are in Historical Palestine and around $50 \%$ of them are in Diaspora.

A recent population's data, according to the Worldometers (2020), indicates the following: 1) The current population of the 1967-OPT is 5,132,172 as of September 30, 2020, based on the latest United Nations' estimates; 2) The OPT's population is equivalent to $0.07 \%$ of the world's total population; 3) The OPT ranks number 121 in the list of countries (and dependencies) by population; 4) The population density in the OPT is 847 per $\mathrm{km}^{2}$ $\left(2,195\right.$ people per $\mathrm{mi}^{2}$ ); 5) $80 \%$ (equivalent to $4,083,476$ people in 2020 ) of the OPT's total population is urban; 6) The population's median age in the OPT is 20.8 years; and 7) The OPT's total land area is $6,020 \mathrm{~km}^{2}\left(2,324 \mathrm{mi}^{2}\right)$.

According to the Israel Central Bureau of Statistics (ICBS), as of April 2018, Israel (within the 1948-Green Line), has a population of approximately 8.842 million, including 6.589 million Jews (74.5\%); about 1.849 million Arabs (20.9\%); and about 0.404 million defined as "others" (JVL 2018). Judging by the current trends in population, experts predict that the population of Israel will reach 10 million by 2025 or sooner (JVL 2018). By the end of 2017, the number of Palestinians and Israelis in Historical Palestine was almost equal, and by the end of 2020, the number of Palestinians in Historical Palestine will be 7.12 million, compared to 6.96 million Jews (Figure 4). This means that in the near future the number of Arab Palestinians will exceed the number of Jews in Historical Palestine by approximately 160,000 .

Figure 4: Number of Palestinians and Jews living in Historical Palestine 2010-2020 (PCBS 2016b).

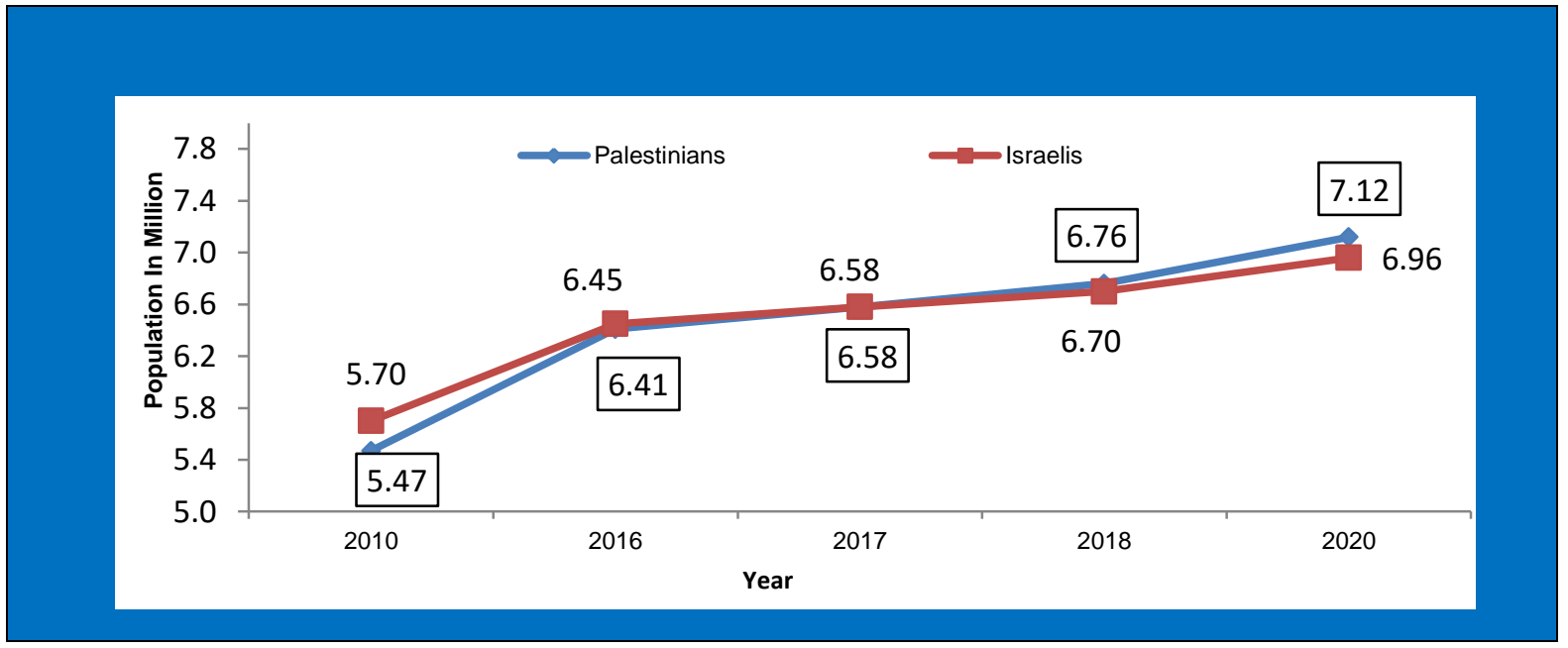

Based on the Population Registry of Israel's Interior Ministry, there are 406,302 Jews living in the settlements of the occupied West Bank (Figure 2) as of 31 December 2015, in addition to 360,000 Jews in the colonies (Figure 2) of East Jerusalem and surrounding areas (Arutz Sheva 2017), totalling around 800,000 inhabitants or even more, which constitutes approximately $13 \%$ of the Jewish population in Historical Palestine. According to international law, the Jewish settlements (more than 230) in the OPT are illegal, as they 
constitute a violation of the "Fourth Geneva Convention" (IIAO 2017). With an estimated net average annual rate of $3.44 \%$ between 2003 and 2007, the growth rate of the Jewish settlers' population in the occupied West Bank is nearly double $(1.79 \%)$ that of the overall Israeli population during the same period (The World Bank 2008). Over the last 30 years, the number of the Jewish settlers in the occupied West Bank grew by 330,000 (Berger 2017).

The illegal confiscation of Palestinian lands and the illegal construction of the Jewish settlements and the Israeli Segregation Wall on the confiscated lands were done with the aid from the Israeli Ministry of Housing and the Jewish Settlement Division, which belongs directly to the "World Zionist Organization" (The World Bank 2008). To ensure that settlers can travel with relative ease and safety between the West Bank and Israel and between the Jewish settlements themselves, a system of segregated roads reserved for Israeli use has been developed (ibid.). Researchers, including Israelis, have begun to talk about "Apartheid Israel" many years ago (Shimoni 1980). A new United Nations' report accuses Israel of having established "An Apartheid regime that oppresses and dominates the Palestinian people as a whole" (ESCWA 2017; White 2017).

\section{Population Distribution in the Occupied Palestinian Territories}

According to the 2006 population's data (PCBS 2006a; PCBS 2006b), the natural growth rate in the OPT was 3.3\% (with 3.0\% in the West Bank and 3.8\% in the Gaza Strip). Approximately $53.5 \%$ of the total Palestinian population lives in urban areas (distributed as $46.7 \%$ in the West Bank and $63.7 \%$ in the Gaza Strip), and the remaining part (46.5\%) of the population lives in rural areas and refugee camps (PCBS 2006a; PCBS 2006b). Currently, $80 \%$ of the OPT's population are living in rural areas (Worldometers 2020), as already mentioned and also as indicated below. This means that the Palestinian population in urban areas has increased by $26.5 \%$ over 14 years only; i.e. from $53.5 \%$ (as it was in 2006) to $80 \%$ (as it is now in 2020). The sex (male/female) ratio was and is still 103/100. The age structure of the Palestinian population in the OPT indicates that the Palestinian community is the youngest in the region. As high as $45.7 \%$ of the total population is less than 15 years old, while only $3 \%$ of the total population is above 65 years old (PCBS 2007; WPR 2020). This can be attributed to the high fertility rate and the decline in child mortality. The average birth rate in the OPT is over 4 children to every woman (WPR 2020). The Palestinian population in the OPT is growing at about $2.65 \%$ per year (WPR 2020), which is $33 \%$ higher than Israel's growth rate. According to the UN News (2016), the fertility rates in the OPT (West Bank and Gaza Strip) are twice the rate of those in the more advanced areas in the region-a trend that is expected to bring its population from 4.7 million (in 2016) to 6.9 million by 2030 and to 9.5 million by 2050. The highest rate of growth is expected to occur in the Gaza Strip, where the 2016-population of 1.85 million will reach 3.1 million by 2030 and 4.7 million by 2050 .

The continuing growth in population and the small area of land available to the Palestinians in the OPT, as a result of the Israeli restrictions and other activities (such as the confiscation of Palestinian lands and the illegal building of the "for-Jews-only" settlements and bypass roads, as well as the Israeli Segregation Wall (with a total length of more than 700 
$\mathrm{km}$ ), have increased the population's density throughout the Palestinian localities. In 2005, the average population's density in the West Bank reached 432 capita/ $\mathrm{km}^{2}$ of the total area, while in the Gaza Strip it reached 3,981 capita $/ \mathrm{km}^{2}$ of the total area. Within the urban areas, the population's density reached 6,842 capita $/ \mathrm{km}^{2}$ of the total built-up area in the West Bank, and 7,485 capita $/ \mathrm{km}^{2}$ of the total built-up area in the Gaza Strip (Salem et al. 2007). According to the Palestinian Central Bureau of Statistics (PCBS 2010), the number of Palestinians in the OPT was 3,935,249 in 2009, resulting in a calculated population's density of 654 capita per $\mathrm{km}^{2}$, of which 433 capita $/ \mathrm{km}^{2}$ in the West Bank including East Jerusalem, and 4,073 capita $/ \mathrm{km}^{2}$ in the Gaza Strip. By mid-2017, the population's density in the OPT was generally highest at $823 \mathrm{capita} / \mathrm{km}^{2}$, particularly in the Gaza Strip where it was 5,324 capita $/ \mathrm{km}^{2}$, compared to a lower population's density in the West Bank of $532 \mathrm{capita} / \mathrm{km}^{2}$ (PCBS 2017a).

\section{Population of the Refugee Camps in the Occupied Palestinian Territories}

According to the UNRWA records of the "Palestinian Refugees in the Near East", there are currently 27 camps in the OPT, including 19 camps in the West Bank (with approximately 810,000 registered refugees as of December 2016), and 8 camps in the Gaza Strip (with approximately 1.3 million registered refugees out of 1.9 million total population (UNRWA $2016 \mathrm{a} ; 2016 \mathrm{~b}$ ). About $16 \%$ of the total Palestinian refugees live in the West Bank, making up $27.2 \%$ of the total population of the West Bank. On the other hand, $22.6 \%$ of the total Palestinian refugees live in the Gaza Strip, making up $68.4 \%$ of the total population of the Gaza Strip. About 15\% of the total Palestinian refugees in the OPT (West Bank and Gaza Strip) still live in camps. The rest of the Palestinian refugees (85\%) left the camps due to overcrowding and lack of proper housing and services (PCBS 2005a; PCBS 2005b; Awad et al. 2007; Wikipedia 2020c). The population's density in the Palestinian refugee camps is generally high, exceeding 50,000 persons per $\mathrm{km}^{2}$ in some camps, whereas the population's densities in the West Bank's camps are lower than those in the Gaza Strip's camps. The population's densities in the refugee camps in the Gaza Strip are considered some of the highest population's densities in the world, reaching, on average, 54,015 capita/ $\mathrm{km}^{2}$ (PCBS 2005a; 2005b). The Palestinian refugee camps are considered by some observers as "urban ghettos" with extremely high population's densities (Hanafi 2010). The number of registered refugees in the OPT grew to an estimated 1,551,145 in 2007, growing from 1,136,259 in 1997, representing an increase of 414,886 persons or by $36.5 \%$. The $3.6 \%$ average annual growth of the registered refugee population exceeds the $2.6 \%$ for the non-refugee population in the OPT (UNRWA 2010).

For many years now, Israel, with the support of the USA, has been trying to liquidate the services provided by the UNRWA to more than 5 million Palestinian refugees, with the aim of ending the UNRWA as it has kept the identity of the Palestinian refugees since 1948 (AZC 2018). More pressure from the USA exerted in that direction since Donald Trump became president. President Trump is planning to cut all the US' funding to the United Nations' program (UNRWA) that administers aid to millions of Palestinian refugees, 
alarming the international community and potentially putting the program itself at risk (Underwood 2018).

\section{Population Projections in the Occupied Palestinian Territories}

According to the PCBS projections, the Palestinian population in the OPT (West Bank and Gaza Strip) increased by 35\% (32.7\% in the West Bank, and 39.6\% in the Gaza Strip) from 1997 to 2005. The projection also indicates that the Palestinian population in the OPT will reach 5,879,103 by the year $2020(3,583,187$ in the West Bank and 2,295,916 in the Gaza Strip). This is an increase of $111 \%$ over the period of 1997-2020 (100\% in the West Bank and $131 \%$ in the Gaza Strip). Figure 5 shows the trends of the population increase in the entire OPT, and separately in the West Bank and Gaza Strip over the period of 1997-2020.

Figure 5: Palestinian population's projection (multiplied by 1,000) for the OPT, including the West Bank (including East Jerusalem), and Gaza Strip for the Period of 1997-2020.

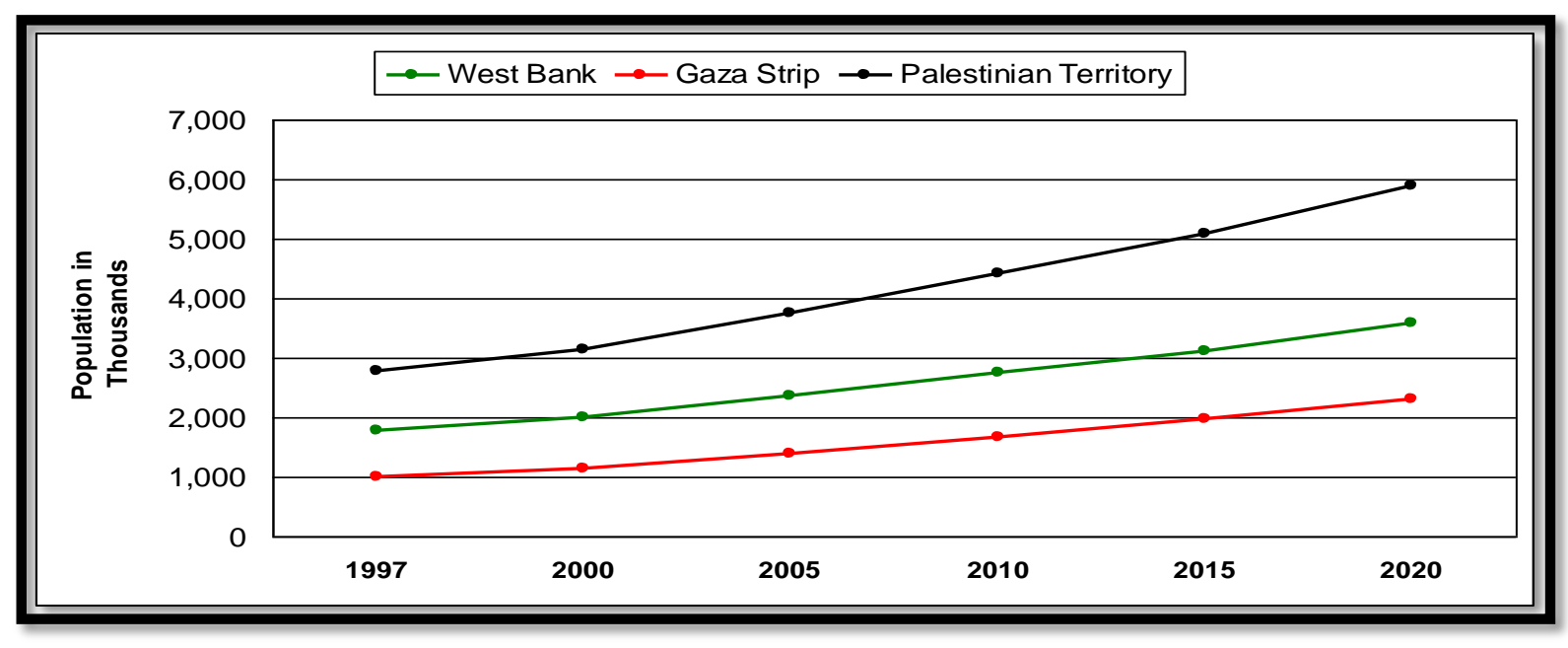

By 2050, the population in the OPT will double to 9.5 million, according to the UN. By 2030, the Palestinian territories would need to add one million new jobs just to keep unemployment at its present rate. According to ILO (2018), there will be a need to create 72,000 new jobs per year by 2030-2035, not including those jobs lacking in the form of unemployment and underemployment - a tall order for the current economy. As for 2016, unemployment was $43 \%$ in the Gaza Strip and 18\% in the West Bank (Akram 2016; Courbage et al. 2016; UN News 2016).

The key challenge facing this demographic increase (the OPT's population will be almost double in about 30 years) is the ongoing Israeli occupation of the West Bank (including East Jerusalem) and the Gaza Strip, represented by the severe restrictions on the movement of people and goods, which results in highly fragmented and distorted local economies with limited capacities for growth. Such complexity and uncertainty have also affected Palestinians' ability to establish long-term policies, plans, and strategies related to development. Until there is a permanent peace agreement, political instability and the 
occupation will remain the primary obstacles to making development gains in the OPT (Courbage et al. 2016).

\section{Development Trends in the Occupied Palestinian Territories}

In this section, two major development trends are investigated, with respect to population and geopolitical conditions in the OPT, which are: 1) Human Trends, and 2) Socioeconomic Trends.

\section{Human Trends}

According to the PCBS' data, the annual growth rate (AGR) of the Palestinian population in the OPT reached $3.3 \%$ in 2005 , which is high in comparison to other nations. During the same year (2005), the crude birth rate (CBR) and the crude death rate (CDR1) were both high, as the CBR reached 37.3 births per 1,000 people, and the CDR1 reached 4.0 deaths per 1,000 people. For the same year, the infant mortality rate (IMR) reached 20.8 per 1,000 live births (PCBS 2005c). These figures indicate that the fertility rate in the OPT is high, which is due to the fact that Palestinian families, in general, favour having many children, and also because females tend to marry at an earlier age. The total fertility rate (TFR) in the OPT in 2003 was 4.6 births. In 2004, the average life expectancy (ALE) for Palestinians in the OPT reached 71.4 years for males and 72.9 years for females (PCBS 2005c).

According to the results from the Multiple Indicator Cluster Survey 2014, the total fertility rate in Palestine declined to 4.1 births between 2011 and 2013, compared to 6.0 births in 1997. At the regional level, the fertility rate in the Gaza Strip was higher than that in the West Bank during 1997-2013, where it reached 3.7 births during 2011-2013 in the West Bank, compared to 5.6 births in 1997, while it reached 4.5 births in the Gaza Strip during 2011-2013, compared to 6.9 births in 1997 (PCBS 2017a). The projected crude birth and death rates during 2016-2020 reveal that the crude birth rate in the OPT is expected to drop from 30.9 births per 1,000 individuals in 2016 to 29.0 births in 2020 . On the other hand, the crude death rate in the OPT is expected to decline from 3.5 deaths per 1,000 individuals in 2016 to 3.4 deaths per 1000 individuals in 2020 .

Table 2 shows that the Palestinian population's rates (including the annual growth rate (AGR), the crude birth rate (CBR), and the total fertility rate (TFR) in the West Bank and the Gaza Strip, as well as in Israel) are the highest rates compared to the population's rates of other countries, while the crude death rate (CDR1) is generally lower than that in other countries. Comparing the infant mortality rate (IMR) between the Palestinian population in the West Bank and the Gaza Strip, on the one hand, and the populations of Arab and nonArab countries, on the other hand, Table 2 shows that it is lower than that in other Arab countries but higher than that in non-Arab countries, but, in general, it is higher in the Arab countries than that in the non-Arab countries. This is a result of better healthcare and environmental conditions, as well as greater access to services (such as waste management, clean water, fresh air, good food, etc.) in the non-Arab countries than those in the OPT and Arab countries. The average life expectancy (ALE) for the Palestinian population in the OPT 
(West Bank and Gaza Strip) lies relatively in the same range as neighbouring Arab countries (Jordan, Syria, Lebanon and Egypt), and is lower than that of non-Arab countries (Israel, Canada, and USA) (Table 2). The difference between the ALE in the OPT's population and the populations in the non-Arab countries is 7.1 years, on average.

Table 2: Comparative human trends in the OPT (West Bank and Gaza Strip) and some other Arab and non-Arab countries (References are given below).

\begin{tabular}{|c|c|c|c|c|c|c|}
\hline Country/Region & $\begin{array}{c}\text { Annual } \\
\text { Growth } \\
\text { Rate (AGR) }\end{array}$ & $\begin{array}{c}\text { Crude } \\
\text { Birth } \\
\text { Rate } \\
\text { (CBR) } \\
\end{array}$ & $\begin{array}{c}\text { Crude } \\
\text { Death } \\
\text { Rate } \\
\left(\text { CDR }^{1}\right) \\
\end{array}$ & $\begin{array}{c}\text { Infant } \\
\text { Mortality } \\
\text { Rate } \\
\text { (IMR) } \\
\end{array}$ & $\begin{array}{c}\text { Total } \\
\text { Fertility } \\
\text { Rate } \\
\text { (TFR) } \\
\end{array}$ & $\begin{array}{c}\text { Average } \\
\text { Life } \\
\text { Expectancy } \\
\text { (ALE) } \\
\end{array}$ \\
\hline West Bank $^{1}$ & 3.0 & 34.5 & 4.1 & 13.9 & 4.1 & 72.5 \\
\hline Gaza Strip $^{1}$ & 3.8 & 42.2 & 3.9 & 20.8 & 5.8 & 71.7 \\
\hline $\begin{array}{l}\text { Palestinians in } \\
\text { Israel }^{1}\end{array}$ & 3.0 & 30.9 & 2.7 & 8.3 & 4.0 & 76.6 \\
\hline Israel $^{2}$ & 1.8 & 21.3 & 5.5 & 4.9 & 2.9 & 79.7 \\
\hline Jordan $^{3}$ & 2.3 & 27.8 & 7.0 & 24.0 & 3.7 & 71.5 \\
\hline Syria $^{4}$ & 2.5 & 23.4 & 2.8 & 24.0 & 3.6 & 70.0 \\
\hline Lebanon $^{5}$ & 1.2 & --- & --- & 28.0 & 2.2 & 73.5 \\
\hline Egypt $^{6}$ & 1.8 & --- & --- & 35.0 & 3.3 & 70.2 \\
\hline Canada $^{7}$ & 0.9 & 10.9 & 7.7 & 4.8 & 1.6 & 80.0 \\
\hline USA $^{7}$ & 0.88 & 14.4 & 8.3 & 7.0 & 2.1 & 77.9 \\
\hline
\end{tabular}

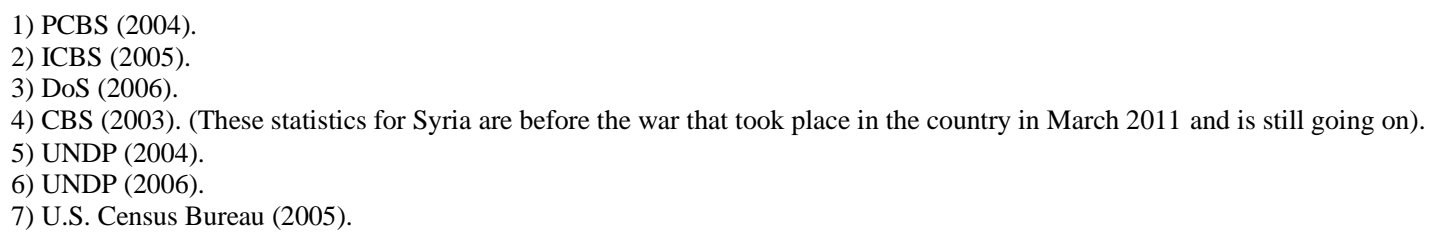

\section{Socioeconomic Trends}

This group of trends includes: 1) Marital Status, 2) Housing, 3) Education, and 4) Health.

\subsection{Marital Status}

The social trends in the OPT have changed during the last three decades or so. For example, the median age at the first marriage in the OPT (West Bank and Gaza Strip), throughout the period 1988-1992, was 18.5-19.1 years. Approximately a decade later (in 2001), the median age at first marriage increased to 24.2 years for men and 19.0 years for women (PCBS 2005d). The increase in the median age at the first marriage indicates an increase in reproductive awareness amongst both women and men, and an increase in their desire to complete their higher education before marriage, as well as the fact that marriage has become 
very expensive, meaning that many people below the age of 30 years cannot afford the costs associated with marriage.

As a result of the increase in population in the OPT, the crude marriage rate (CMR) and the crude divorce rate (CDR2) have increased to reach 7.6 marriages per 1,000 individuals and 1.1 divorces per 1,000 individuals, respectively (PCBS 2005a). However, the divorce rate in the OPT has increased rapidly in recent years. The Palestinian Supreme "Shari' $a$ " Council announced that almost half of the marriages in the West Bank have dissolved before the wedding night and before those marriages are consummated, due to a variety of reasons. These include the newly introduced "Khole" (or Kholo') law, which enables women to break off a union before the marriage is completed, losing all dues and rights (Nazaal 2012). More than 24,000 marriage contracts were registered in West Bank-based Shari'a Courts during 2013. During the same period, more than 5,000 divorce cases were registered, producing a West Bank's divorce rate that exceeded 20\% (Nazaal 2014). In the Gaza Strip, according to the "Palestinian High Judiciary Council" in Gaza, the marriage rate decreased by $8 \%$ in 2016, while the divorce rare increased by $2 \%$ for 2015 . The CMR (crude marriage rate) in the OPT by governorate for the period 1997-2016 was between 2.8 per 1,000 individuals (in the Bethlehem Governorate in the West Bank) and 12.4 per 1,000 individuals in the Gaza Strip (PCBS 2016c). Meanwhile, the CDR2 (crude divorce rate) in the OPT by governorate for the period 1997-2016 was between 0.6 per 1,000 individuals for the Governorate of Qalqilya and 2.7 per 1,000 individuals for the Governorates of Ramallah/Albireh and Tulkarm (PCBS 2016d). These figures indicate that the divorce rate has generally increased in the OPT between 2009 and 2016.

In addition to the higher costs of marriage, higher rates of poverty and unemployment, and the wide-spread use of social media, there are other factors behind the decreased marriage rates and the increased divorce rates in the OPT. Poverty and unemployment have been blamed for these and other social changes in the OPT (MEM 2017). In the OPT, almost one in three people (33.3\%) were living below the poverty line in 2017 (PCBS 2017b). With $53 \%$ of individuals in the Gaza Strip found to be poor in 2017, the poverty rate for the Gaza Strip was almost four times higher than that for the West Bank, which was 13.9\%. This reflects the catastrophic effects of the ongoing blockade on the Gaza Strip since 2007 (PCBS 2017b; Jaber and Zuhour 2018). Regarding the social media effects, many religious figures in the West Bank agree that social media platforms have been a key reason for the increasing number of divorce cases in the OPT (Nazaal 2014).

Among the other reasons for the high divorce rates in the OPT is, for instance, the growing popularity of so-called "women's associations and foundations" (NGOs), which are, presumably, concerned with legal and social issues of women in Palestinian society. However, rather than helping women to continue their family life with their husbands and children, peacefully, successfully, and in a satisfying manner; and instead of helping women work to solve their problems within the marriage, women's associations and foundations have helped increasing the number of divorce cases in Palestinian society, under the pretext of protecting women's rights, according to officials at Shari'a Courts. Those organizations (NGOs) incite Palestinian women to rebel against their husbands, which ultimately lead to divorce and a collapse of the core family, instead of reconciliation between couples. The main reason behind those women's associations and foundations that encourage divorce 
among couples in the OPT is the huge funds that they receive from international organizations. However, many of the NGOs, including those concerned with women's issues, do not publish financial information, reflecting a lack of transparency (NGO Monitor 2020). Rather being concerned with the well-being of women, children, and families in Palestinian society, as they claim, those NGOs are concerned with how much money they can collect from international organizations (see, for instance, Ash-Shami 2013).

However, the situation in the OPT is not much different than that in some Western countries, where feminist movements have become stronger and one of their interests is divorce among couples. Data from the US' Office for National Statistics shows that there were 118,140 divorces in 2012, 65\% of which were granted to women (Daubney 2015). A new survey has shown that women in the US are now initiating $69 \%$ of divorces - and they are increasingly doing it because they claim that their husbands do not pull their weight with housework and childcare. The survey indicates that these women are heading to the divorce courts because they have been "inspired by second wave feminist thinking that claims "marriage is inherently hostile to women"' (Daubney 2015).

\subsection{Housing}

Housing and urban planning trends have been affected by the geopolitical conditions as a direct result of the Israeli occupation of the Palestinian Territories (the West Bank, including Jerusalem, and the Gaza Strip). With the Israeli restrictions on the OPT, the area available for Palestinians to build on is decreasing daily. With the expansion of the Jewish settlements in the OPT, especially in Area $C$, and with the increase in the Palestinian population, this challenge has led to lack of housing units and, as a result, to overcrowding in the alreadyexisting housing units. If the current situation continues its negative trends and the population continues to increase, then Palestinian society will witness in the near future a severe deficit in the housing units and a considerable deterioration in the living conditions of the Palestinian households. In addition, the real estate prices are increasing, because of the seizure of Palestinian lands by the Israeli occupation authorities, and due to the fact that many Palestinian citizens living in East Jerusalem and its neighbourhoods are leaving their houses and, in turn, they buy or rent houses in the West Bank. This Palestinian exodus from Jerusalem is due to the high taxes and licensing costs imposed on the Palestinians in East Jerusalem and its neighbourhoods by the Israeli occupation authorities. Also, the President Trump's decision of moving the US Embassy from Tel Aviv to Jerusalem has already put extra pressures on the Palestinians, in general, and on the Palestinian Jerusalemites who live in Jerusalem, in particular. President Trump's decision, according to the European Union (EU), is "unwise", as it represents a strong violation of international law and will exacerbate tensions in the region and, therefore, it was strongly condemned by the EU and the rest of the world (TTOI 2018).

The PCBS estimated that the Palestinian population needed about 130,000 housing units for the period 2006-2010 (PCBS 2005b). During that period, more than three-quarters of the housing units in the OPT were owned by a family member. In 2016, the percentage of Palestinian households with a family member owning a housing unit was about $77 \%$, of which $79 \%$ were in the West Bank and $72 \%$ were in the Gaza Strip. Meanwhile, the 
percentage of the households that were living in rented houses in the OPT was 9\%, of which $10 \%$ were in the West Bank and 7\% were in the Gaza Strip (PCBS 2017a).

Three scenarios were put forward by the PCBS to project population, households, and housing units in the OPT for the period 2006-2020 (PCBS 2005c). These scenarios are: 1) The Low Growth Scenario (LGS), assuming that the economic situation will deteriorate as a result of slow economic growth; 2) The Medium Growth Scenario (MGS), assuming that the economic situation will remain the same; and 3) The High Growth Scenario (HGS), assuming that the economic situation will improve. Table 3 shows the results projected for the three scenarios in the OPT (West Bank and Gaza Strip) for the period 2006-2020. Three years after the three-scenario projections were suggested, the first scenario (LGS) seemed to be the dominant one affecting Palestinian society, as the economic growth was really slow due to many factors. The most influential factors were/are political and geopolitical ones in nature, leading to steady deteriorations.

Table 3: Percentage increase in population, households, and housing units in the OPT (West Bank and Gaza Strip) during the period 2006-2020, according to three scenarios: 1) Low Growth Scenario (LGS); 2) Medium Growth Scenario (MGS); and 3) High Growth Scenario (HGS) (PCBS 2005c).

\begin{tabular}{|l|c|c|c|c|c|c|}
\hline Scenario & \multicolumn{3}{|c|}{ West Bank } & \multicolumn{3}{c|}{ Gaza Strip } \\
\cline { 2 - 8 } & $\begin{array}{c}\text { Population } \\
(\%)\end{array}$ & $\begin{array}{c}\text { Households } \\
\end{array}$ & Housing Units & Population & Households & Housing Units \\
\hline LGS & 43.1 & 43.1 & 43.1 & 50.9 & 50.9 & $\mathbf{5 0 . 9}$ \\
\hline MGS & 51.1 & 51.1 & 51.1 & 65.2 & 65.2 & $\mathbf{6 5 . 2}$ \\
\hline HGS & $\mathbf{7 0 . 6}$ & $\mathbf{7 0 . 6}$ & $\mathbf{7 0 . 6}$ & $\mathbf{8 2 . 9}$ & $\mathbf{8 2 . 9}$ & $\mathbf{8 2 . 9}$ \\
\hline
\end{tabular}

It is important to note that since the eruption of the Second "Intifada" (Second Public Uprising) in the year 2000, the Israeli occupation authorities have demolished thousands of Palestinian homes for supposed "security reasons" or because the home owners did not obtain licenses from the Israeli occupation authorities to build their homes, as claimed by the Israeli Government. The land-use, following the destruction of Palestinian homes and entire neighbourhoods, includes building new Jewish settlements, expanding the already-existing Jewish settlements, and continuing the construction of the Israeli Segregation Wall, as well as the bypass roads (for-Jews-only) to serve the settlements and their Jews-only-settlers, strengthening the impacts of the Apartheid system and its effectiveness in the occupied West Bank. This is represented lately, for example, in the Israeli military decision supported by the Israeli Supreme Court to demolish the Bedouin's village of "Khan Al-Ahmar" that belongs to the Jerusalem Governorate and locates between two illegal Jewish settlements (Ma'ale Adumim and Kfar Adumim), about $8 \mathrm{~km}$ east of the City of Jerusalem in the occupied West Bank. The Israeli decision that will make about 200 people, including around 100 children, homeless has been strongly condemned by the international community, as it has been considered as a "war crime" (BBC 2018; Lazaroff 2018). According to the 1931 Census of Palestine, conducted by the British Mandate authorities, the village had a population of 27 
living in 3 houses (Mills 1932; Wikipedia 2020d). This means that the Khan Al-Ahmar village was founded a long time before the state of Israel was established in 1948.

In the period 2000-2006, the total number of the Palestinian homes demolished by the Israeli occupation authorities, in the West Bank alone, was 1,934. In the Gaza Strip, the house demolitions by the Israeli occupation authorities were more extensive, where the number of the Palestinian homes demolished in the period 2003-2006 was 4,863. It is reported that since 1967, the Israeli occupation authorities have demolished 48,000 houses (Aaliyah 2017). The Israeli occupation authorities do not destroy only homes, but also buildings and structures that belong to Palestinian citizens and organizations, as well as to the Palestinian Government. Hundreds of these structures were funded by international donors for humanitarian assistance, including the European Union (EU). Within the first three months of 2016, over 150 EU-funded homes and structures were demolished by Israel in the West Bank (ibid.). These included even solar-energy facilities that cost hundreds of thousands of dollars, funded by European governments, such as the Dutch Government (Salem 2018; Salem $2019 b$ ). According to UN figures, Israel is demolishing more Palestinian homes now than ever, which is illegal under international law. The $53^{\text {rd }}$ Article of the 1949 Fourth Geneva Convention (Wikipedia 2020e) states that, "An occupying power is prohibited from destroying any property belonging to individuals, organizations, or the state". Home demolitions are one of the most devastating hardships that Palestinian citizens frequently face, especially in the occupied West Bank, including East Jerusalem. The most painful thing to Palestinians is that, in many cases, they have to demolish their own homes because they do not want the Israeli soldiers get in, or because they want to avoid incurring high demolishing fee to be paid to the Israeli occupation authorities (MA'AN 2017; Farrell and Sawafta 2018; Mcardle 2018).

\subsection{Education}

In 1994, and according to the Oslo Agreement signed in 1993, the Palestinian Ministry of Education and Higher Education (MoEHE) took control over the educational system in the OPT after 27 years of Israeli military control. Since then, the MoEHE has tried to modify the system to match the current needs of the Palestinian population, and to develop the Palestinian curricula to acceptable standards. As a result, the literacy rate in the OPT has increased from $84.3 \%$ to $92.9 \%$ for the period 1995-2005 (PCBS 2005e). This 8.6 percentage increase in the literacy rate in about a 10 -year period is considerable, especially under the difficult geopolitical conditions affecting the Palestinian society in the OPT. In addition, this literacy rate is higher among females than males, as it noticeably increased, for the same period of time, by $15.5 \%$ among females and by $5.9 \%$ among males (ibid.). It is, however, believed that these increases represent a shift in attitude concerning females' education, along with better financial resources before the economic downturn that followed the outbreak of the Second Intifada.

The 2016 data revealed that the percentage of individuals (aged 15 years and above), who completed university education (a Bachelor degree and above), was 14\% while the percentage of individuals who did not complete any stage of education reached 9\% (PCBS 2017c). In 2016, the female illiteracy rate was three and half times higher than that of males. 
The illiteracy rate among individuals aged 15 years and over in the OPT was $3.1 \%$ in 2016 with the gap in illiteracy among males and females at $1.4 \%$ and $4.8 \%$, respectively (ibid.). However, generally speaking and despite the encouraging education figures given above, education in the OPT has been getting worse. In her study conducted in 2015, Ramahi, according to a university faculty member, states: "Public schools are failing our youth. The quality of education has been worsening rapidly... Students are promoted to higher grades despite inabilities to read and write... It's intolerable” (Ramahi 2015: 6). Ramahi (2015: 6-7) continues:

\begin{abstract}
Several university faculty members reported that their students are not capable of performing basic analytical and communication skills necessary for a post-secondary education. Alarmingly, one [university lecturer] indicated that up to $90 \%$ of her students did not meet basic university level academic standards. The vast majority of my students can't do a research paper. They're so used to memorization that they can't think for themselves. There is no self-confidence or ability to think critically. How can they advance in life or contribute to society? How did we let things get so bad?
\end{abstract}

The main supervising authority for schools in the OPT is the governmental sector that belongs to the Palestinian Authority, although some schools are supervised by the UNRWA (United Nations' Relief and Work Agency), and some other schools are private. All the Palestinian localities have governmental schools, meanwhile the UNRWA schools are distributed in the refugee camps and in some small villages, and the private schools are primarily distributed in the cities. The statistics of the scholastic year 2005/2006 indicates that there were about 2,276 schools in the OPT, providing educational services to about $1,078,500$ students. According to more recent reports, the number of schools in the OPT is 2,963 schools, including basic and secondary schools, distributed as 2,249 in the West Bank and 714 in the Gaza Strip (PCBS 2017d). For the school year 2016/2017, the number of students in the OPT was 1,376,589, distributed as 783,871 in the West Bank and 592,718 in the Gaza Strip (ibid.).

The number of students enrolled in the Technical and Vocational Education and Training (TVET) system, belonging to the MoEHE of the Palestinian Authority, for the year 2014 was 2,644, including 2,428 students in the industrial stream and 216 students in the agriculture stream (MoEHE 2014). In 2014, the total number of TVET schools in the OPT was 76 institutions, funded by various ministries of the Palestinian Authority (such as the MoEHE, Ministry of Labour, and Ministry of Agriculture); UNRWA; the private sector; and NGOs; as well as some international organizations, such as the GIZ (Deutsche Gesellschaft für Internationale Zusammenarbeit, $\mathrm{GmbH}$ - German Society for International Cooperation, Ltd.). The programs offered to trainees/students by these schools range in time's length from less than two days to two years (MAS 2015).

Regarding the higher education in the OPT, until 2005/2006 there are 43 institutions, including 11 universities, 13 university collages, and 19 community colleges, hosting more than 135,000 students (MoEHE 2006). In 2015/2016, the number of higher education institutions in the OPT jumped to approximately 50, including universities, university colleges, and community colleges distributed in the West Bank and Gaza Strip, with up to 
221,000 students (approximately 40\% males and 60\% females) (RecoNow 2016; PCBS 2017d; Wikipedia 2020f).

In the OPT, for the year of 2015/2016 the average students/teacher, students/computer, and students/classroom ratios in the private schools are lower than those in the public (governmental) schools, which are, in turn, lower than those in the UNRWA schools (Table 4) (PCBS 2017c; PCBS 2017d). Table 4 demonstrates that the classes are relatively crowded with not enough teachers and not enough computers, and they have insufficient classroom's spaces to meet acceptable standards of education.

Table 4: The ratios of students/teacher, students/computer, and students/classroom for all stages in private schools, public schools, and UNRWA schools (PCBS 2017c; PCBS 2017d).

\begin{tabular}{|l|c|c|c|}
\hline Schools & $\begin{array}{c}\text { Students/Teacher } \\
\text { Ratio }\end{array}$ & $\begin{array}{c}\approx \text { Students/Computer } \\
\text { Ratio }\end{array}$ & $\approx$ Students/Classroom Ratio \\
\hline Private Schools & $16 / 1$ & $16 / 1$ & $24 / 1$ \\
\hline Public Schools & $21 / 1$ & $22 / 1$ & $34 / 1$ \\
\hline UNRWA Schools & $29 / 1$ & $47 / 1$ & $42 / 1$ \\
\hline Total's Average & $22 / 1$ & $28 / 1$ & $33 / 1$ \\
\hline
\end{tabular}

\subsection{Health}

The Palestinian Authority took responsibility for the supervision, regulation, licensing and control of the entire health-service sector beginning in 1994 (i.e. since it took administration's control over the OPT). The health services are provided mainly by the Palestinian Ministry of Health $(\mathrm{MoH})$, and through the private sector, non-governmental organizations (NGOs), and the UNRWA. However, the OPT ranks $113^{\text {th }}$ in the Human Development Report 2015, published by the United Nations, which puts the OPT in the medium development category (UNDP 2015). The Palestinian population in the OPT obtain their health services from primary healthcare's clinics and centers (PHCs), and from hospitals. In the OPT, until 2005 there were 667 PHCs, with an average ratio of persons per center equalling to 5,752. In addition, there were 76 hospitals in the OPT (MoH 2006). The percentage of the Palestinian population that had health insurance in 2004 was $76.1 \%$, distributed as $65.8 \%$ in the West Bank and 93.8\% in the Gaza Strip (PCBS 2005f).

According to a report issued by the PCBS (2018), Palestine (the OPT) has 80 hospitals, with a total of 6,006 beds, whereby 26 of these are governmental hospitals, offering 2,979 beds or $54.3 \%$ of the total number of beds. Also, 54 hospitals are private, with 2,508 beds or $45.7 \%$ of the total number of beds. In addition, there are 750 PHCs, including 603 in the West Bank and 147 in the Gaza Strip. The governmental PHCs account for approximately $61.3 \%$ of the total number of the PHCs in the OPT (ibid). In 2012, the number of physicians registered with the "Palestinian Doctors Association" was 8,810. The average number of physicians per 1,000 people was 2.2 (2.3 in the West Bank and 2.2 in the Gaza Strip). In the same year, there were 11,633 registered nurses. The average number of nurses per 1,000 people was 2.7 (2.2 in the West Bank and 3.4 in the Gaza Strip). A statistics for 2015 showed that the average number of the health sector's workers rose significantly, with the number of 
general practitioners and specialists reaching 10,562. However, the ratio of hospitals and hospital beds to the population has largely stayed the same (Fanack 2016; Salem 2020).

In the Gaza Strip, in particular, the health conditions are really catastrophic, as they have been severely deteriorating for a long period of time, especially since the blockade (military siege) was enforced by the Israeli occupation authorities on the Gaza Strip in June 2007. According to Dr. Gerald Rockenschaub, the WHO Head of Office for the West Bank and Gaza (WHO 2018):

The deteriorating humanitarian situation is extremely worrying. Hospitals in Gaza are overwhelmed with the influx of injured patients. With further escalations expected during the coming weeks, the increasing numbers of injured patients requiring urgent medical care is likely to devastate Gaza's already weakened health system, placing even more lives at risk.

Another alarming health issue in the OPT is the widespread use of drugs among youth in the Palestinian society. According to surveys conducted in the last few years (Massad et al. 2016; PNIPH 2017), substance use exists especially among youth, even in socially conservative communities. The reasons behind drug use and drug addiction and abuse, as well as alcohol drinking in the OPT, include the following: 1) To cope with stress, for fun, and out of curiosity; 2) To challenge society, due to the influence of media (especially social media), peer pressure, poverty, unemployment, and chronic and acute exposure to political violence;

3) To increase productivity in an environment of hard-work and long-working hours; 4) The availability and easy access to drugs; 5) Being a wife or a child of someone addicted to drugs; and 6) Myths about the effect of some drugs on improving sexual performance (Massad et al. 2016; PNIPH 2017). "The level of drug use [in the occupied West Bank] today is really scary. It increases day by day. The seriousness of these drugs is like a nuclear bomb; Like dropping a nuclear bomb on a small country” (McQueeney 2017: online).

\section{Geopolitical Impacts}

The Palestinian people in the OPT have been greatly affected by international migration outside the OPT's boundaries, and by internal migration among the Palestinian governorates and localities within the OPT. However, movement of people between the West Bank and the Gaza Strip is totally prohibited by the Israeli occupation authorities; movement between the different cities and between the governorates of the West Bank is also restricted due to the presence of hundreds of Israeli checkpoints with dozens of soldiers stationed at each; movement to occupied East Jerusalem is allowed only for women and men who are above 50 and 60 years of age, respectively, or for sick people who hold permits issued by the Israeli occupation authorities; and movement to Israel is allowed only for those who can obtain various kinds of Israeli permits, which is essentially not easy at all.

The Israeli restrictions and closures to enter occupied Jerusalem and to move freely among Palestinian cities and governorates in the OPT due to the closures and hundreds of checkpoints among the Palestinian governorates and localities; the construction of the Israeli 
Segregation Wall (Figure 3; Figure 6); the high rates of unemployment; the enormous deterioration in the standards of living in the OPT; the widening gap between the ones who have and the ones who have not are all important factors that have forced many Palestinians to leave their homes and move to other localities, or to leave the OPT permanently, migrating to other countries in an attempt to find a better life.

Figure 6: Map showing the Israeli Segregation Wall (ISW) and the Segregation Zones around and within the occupied West Bank (Salem 2007).

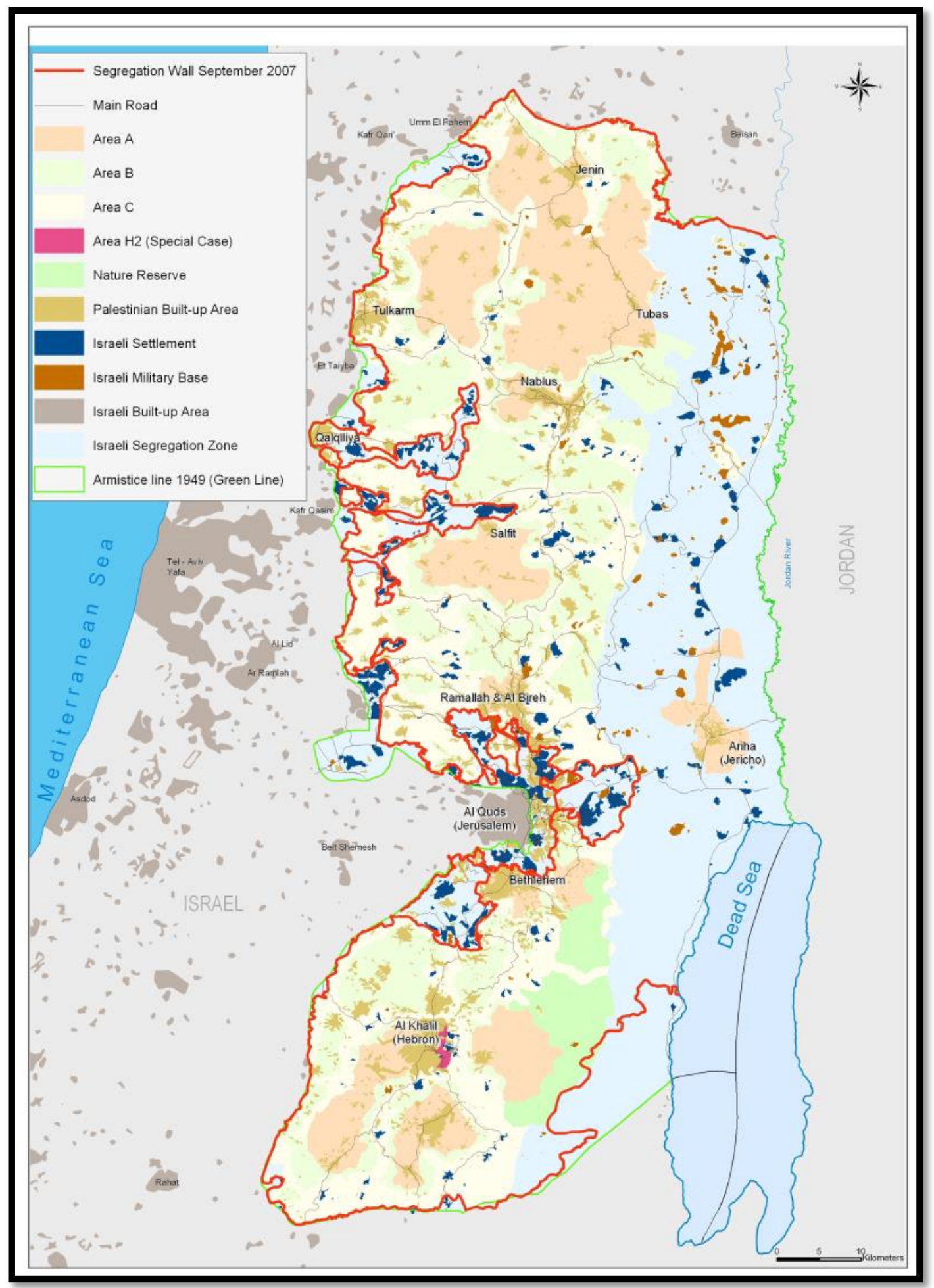


However, it has been difficult to study the external migration due to the lack of comprehensive data, as a result of the Palestinian Authority's inability to control the borders, because they are fully under the control of the Israeli occupation authorities. It is impossible for the Palestinian Authority to develop any policy for managing the mobility, particularly as Palestinians are not allowed to access the Israeli Ben Gurion Airport in Tel Aviv; because Jordan carefully controls the transit of Palestinians through its territory; and also because Egypt closes its borders with the Gaza Strip. Additionally, circulating within the OPT is extremely difficult because of hundreds of the Israeli check points existing everywhere (EUI, RSCAS, MPC 2013). These extraordinary harsh and inhumane conditions have made the occupied West Bank and the besieged, occupied Gaza Strip big prisons.

Just in the last few years, tens of thousands of Palestinians have already left the OPT to other countries because of the hardships they experienced under the Israeli military occupation, as well as due to the lack of any opportunities to improve their lives. Internally, according to the PCBS data, the percentage of Palestinians who changed their place of residence during the period 2000-2004 was 3.3\% of the total population, where most of them moved from rural areas to cities (PCBS 2005a; PCBS 2005c). This is roughly equal to more than 100,000 people. Just between 2005 and 2009 roughly 33,000 Palestinians left permanently the OPT (PCBS 2011; EUI, RSCAS, and MPC 2013). On the other hand, one of the advantages of the Oslo Agreement is that it allowed the return of around 100,000 dispersed Palestinians to the OPT in the 1990s. However, the political impasse, the security chaos, and the worsening of socioeconomic conditions have led, in the 2000s, to new waves of outward flows, particularly of young and well-educated individuals.

Since the Israeli Government began the construction of the Segregation Wall (ISW) in 2002 (Figure 3; Figure 6), the Palestinian people have dramatically suffered, especially due to the Wall's devastating impacts on their lives. As a direct result of the Wall, many Palestinians have been severely suffering, which has resulted in inward and outward migration, loss of jobs, loss of homes, loss of lands, loss of water resources, loss of schools, loss of clinics, poverty, more restrictions on movement of goods and people, etc. The construction of the Wall, with a total length of more than $700 \mathrm{~km}$ has also resulted in reduction of access to public services, like emergency healthcare, and it has also impacted, very badly, the educational quality and social relations.

The ISW has affected not only those Palestinians living directly on either side of the Wall, but it has also affected the socioeconomic conditions of many other communities in the OPT, at large. Where the Wall has been constructed, Palestinians have been facing economic hardships to restrictions that limit their movement, and, as a result, are unable to reach their lands to harvest crops, to graze animals, or, at least, to earn a living by reaching a place of employment. Palestinian residents who are close to the Wall have also been cut off from schools, universities, and specialized healthcare centers. Additionally, the Wall has fragmented farms and communities, and has isolated residents from social support networks.

It is worth mentioning that the international community, through the International Court of Justice (ICJ) in The Hague, The Netherlands, and through many other international organizations have strongly condemned the construction of the Wall (ISW). According to the ICJ's ruling of 9 July 2004 (about two years after the Israeli Government had decided to build the Wall), the ICJ issued the following: "The ICJ concluded that the construction of the Wall 
by Israel on Palestinian lands in the Occupied Palestinian Territories is contrary to international law. Accordingly, the ICJ has stated the legal consequences that are to be drawn from that illegality" (UN 2004: online).

One of the most controversial laws that the Knesset (the Israeli Parliament) has recently legislated is what is known as "The Jewish Nation-State Law". Many observers consider this law as another form of "Apartheid Israel", which will badly affect, not only the native Palestinian citizens within the state of Israel, but also the native Palestinian citizens in the Occupied Palestinian Territories, because all Palestinians, according to the new law, are considered as "non-Jews". This represents another form of the Israeli-Zionist racism against the native Palestinians of the land - Historical Palestine. According to Pappé (2018: online),

The Israeli nationality law is now a fact. Its full name is "Israel, the nation state of the Jewish people". It states that "Eretz Israel" (Historical Palestine) is the homeland of the Jewish people and that the state of Israel is the nation state of the Jewish people. Furthermore, only the Jews have the right to self-determination in Israel. Hebrew is the only official language (until now Arabic was also an official language) and Arabic has a special status, which is undefined in the text of the law. The law defines future Jewish settlements, which some would call colonization, in historical "Eretz Israel" (Israel and the occupied territories) as of supreme national value and vision. It grants religious and national communities the right to maintain a segregated habitat in the state (namely, the practice of having exclusive villages and towns for Jews). ${ }^{2}$

The new Israeli law does not come in a vacuum, but it is deeply rooted in the ideology of Zionism. Machover (2018: 69 - Abstract) commented on this by asking,

How can Zionism claim that Israel is the nation-state of the Jewish people, since the only attribute shared by all Jews is Judaism, a religion and not an attribute of nationhood in any modern sense of the word? Jews can belong to various nations - a Jew may be French, American, Indian, Argentinean, and so forth—but being Jewish excludes other religious affiliations.

\section{Conclusions and Recommendations}

This article has focused on the geopolitical challenges, complexities, and future uncertainties in the Occupied Palestinian Territories (OPT), with the consideration of some perspectives related to the OPT's land and population. The geopolitical impacts of the Israeli occupation of the Palestinian Territories since 1967, and the Jewish settlements and the Israeli Segregation Wall that are illegally built in violation of international law are investigated in this study. This is in relation to some important issues, including human and socio-economic trends, with the focus on marital status, housing, education, and health. The Israeli activities in the OPT (such as the building of Jewish settlements, the construction of the Segregation Wall, the demolitions of Palestinian homes, the confiscation of Palestinian lands, the presence of hundreds of checkpoints, the daily closures, the 13-year blockade on the Gaza Strip since 2007 , etc.) have resulted in high population density and overcrowding, as well as 
in the lack of harmony in the population's distribution, and a lot of other problems. These, for instance, include high unemployment and poverty rates, as well as high rates of inward and outward migration. The division of the occupied West Bank into three geopolitical zones (Area A, Area B, and Area C); the isolation of East Jerusalem from the West Bank and the Gaza Strip; the isolation of the West Bank from the Gaza Strip; and the isolation of the West Bank and Gaza Strip from Israeli proper behind the Green Line; as well as the total control of the Israeli occupation authorities on the entries to the OPT (Gaza Strip and West Bank, including East Jerusalem) have made the OPT a big prison for more than 5.1 million people.

Based on the data available, and the arguments, investigations, and analyses presented in this study, the following recommendations are suggested, so that they might be taken into serious consideration by decision makers, researchers, academicians, and national and international organizations who/which are concerned with the Palestinian Question, for the sake of: 1) Well-being of the Palestinian people living in the OPT under the Israeli occupation since 1967; and 2) Just peace in the Middle East's region that should recognize the political, human, and civil rights of the Palestinian people in a sovereign Palestinian state on the territories occupied in June 1967, with East Jerusalem as its capital, according to international law. The recommendations are as follows:

1) Urban development plans should take into consideration the increasingly high population density in the refugee camps and should create plans for improving the living conditions in those camps, without compromising on the "Right of Return" for the Palestinian refugees (ancestors and descendants) to their lands and homes in Historical Palestine; i.e. to where they (ancestors) used to live prior to the establishment of the state of Israeli in 1948. This is in full agreement with the United Nations' General Assembly's Resolution 194 , as discussed above.

2) Define acceptable population growth rates and put development plans for communities, while studying and considering the positive and negative impacts on the environment, economy, and sustainable development programs in the OPT.

3) Intensify the creation of community housing projects for young couples and households with limited incomes, in order to decrease the housing density.

4) Intensify the job creation's programs in the rural areas, in order to minimize the internal migration from rural to urban areas.

5) Create job programs to reduce unemployment and poverty rates, which would help reduce rates of external migration, especially among young people and experienced professionals, considering the fact that the lack of employment is the primary cause for migration.

6) Encourage the infrastructure and plans for development, including plans of creating a large number of job opportunities.

7) Increase the support for development of the educational system and institutions, especially the secondary, vocational, and higher education, particularly through digitization (Salem 2020). Also, provide the opportunity for Palestinians to continue their education in the OPT at considerably lower costs. 
8) Encourage scientific research at the Palestinian universities and research institutions, for the sake of improving the living conditions of the Palestinian people, based on future plans and strategies.

9) Hire the right persons for the right jobs, based on qualifications (education, experience, and skills) aside from interventions from individuals and/or institutions and aside from the influences of tribes and political parties and factions, which can guarantee better production, quantitatively and qualitatively.

10) Encourage and support the capacity building and technology transfer programs.

11) Strengthen the public health infrastructure and integrate fragmented health services to unify data reporting for successive health and nutritional assessments.

12) Improve primary healthcare through digitization processes, through developing information and data collection strategies, and through the creation of a uniform national reporting structure to identify and monitor disease trends and their associated risk factors (Salem 2020).

13) Update the immunization programs and increase the capacity for controlling and treating diseases.

14) Provide health education and easily understandable health information, as well as protection and treatment tools for the communities throughout the OPT, especially with the focus on the current outbreak of the Coronavirus disease (COVID-19).

15) Build and develop institutional structures to take responsibility of public development and investment and to increase the quality and scope of the services provided.

16) Increase investments in human resources and services, as well as in education, healthcare, housing, agriculture, water, energy (especially renewable), and other sectors as well.

17) Work on increasing environmental awareness programs, with respect to air, water, soil, and noise pollution, as well as to waste management programs, based on the "Principle of the Three Environmental Rs" (Reduce, Reuse, and Recycle).

18) Work with international organizations to lift the continued blockade since 2007, and to end the military siege enforced by the Israeli occupation authorities on more than two million people living miserably in the Gaza Strip.

19) Work with international organizations to enforce international law and prevent the Israeli occupation authorities from confiscating more Palestinian lands and also from building more illegal Jewish settlements, the illegal Israeli Segregation Wall, and other similar walls around the West Bank and the Gaza Strip.

20) Work with international organizations to end the "Apartheid System" implemented by the Israeli occupation authorities in the Occupied Palestinian Territories.

21) Work with international organizations to put an end for the Israeli policies of demolitions of Palestinian homes, communities, villages, offices, and infrastructures.

22) Combat the increased use of illicit drugs and alcohol, based on the fact that the level of drugs' use in the OPT today is really scary, as it has reached unprecedented levels.

23) Combat financial and political corruption, nepotism, favouritism, abuse of position, political and family considerations, bribery, smuggling, and theft, as well as oppression, resulting from the lack of transparency and justice in Palestinian institutions. Such wrongdoings are clearly observed when it comes to, for instance, employment in the public sector. For instance, AMAN (2013) listed examples of the haemorrhaging of public funds 
in Palestinian municipalities in the West Bank and details of the total debt of the Palestinian Authority's treasury to the municipalities and water authorities which stands at about NIS one billion (NIS: New Israeli shekels - the locally used currency), which equals to approximately USD 300 million, accumulated between 1996 and 2012 (AMAN 2013). In addition, there is continued misuse of the Government's vehicles and other properties by employees, along with suspicions related to other issues (Ramahi 2013; AMAN 2013; AMAN 2015; AMAN 2016; AMAN 2017).

24) Put an end to the exploitation and greed of the banks and large companies for citizens, such as the companies of telecommunications and others that earn billions of dollars every year at the expense of poor citizens. Such behaviours are often supported by the Palestinian Government and the Palestinian Authority, especially in the absence of oversight by a legislative council or any other oversight body (see, for instance, Salem 2020).

25) Call, soon, for free and democratic elections for the Palestinian National Council, the Palestinian Legislative Council, and the Palestinian Presidency, electronically and transparently. Such elections must take into account the participation of all Palestinians in the electoral processes. These must include the Palestinians within the Occupied Palestinian Territories (the West Bank, including East Jerusalem, and the Gaza Strip) and Palestinians in Diaspora outside the OPT.

26) Ensure freedom of expression and freedom of opinion for all Palestinians, and release all Palestinian political prisoners.

\section{Notes:}

1. Further details on the "Question of Palestine" are given in the section entitled "Historical Background".

2. Pappé, Ilan (2018) warns the world by saying that, "International support for racism in Historical Palestine is only going to add fuel to the fire." To learn more about the main points of the new law, see Pappé (2018).

\section{Declaration}

The Author of this article declares the following: 1) Compliance with Ethical Standards, including: The research presented herein does not involve human participants and/or animals; 2) Informed consent: There is no potential of conflict of interest of any kind (financial or otherwise); and 3) Funding: The research presented in this article did not receive any funding from any individuals or organizations.

\section{References}

Aaliyah, Camilia (2017). 'Israel has demolished 48,000 Palestinian homes since 1967', Welcome To Palestine. February 2017, https://www.welcometopalestine.com/article/israelidemolitions-palestinian-homes/ 
Abdallah, Tanya and Swaileh, Khaled (2011). 'Effects of the Israeli Segregation Wall on biodiversity and environmental sustainable development in the West Bank, Palestine', International Journal of Environmental Studies 68 (4): pp. 543-555.

Akram, Fares (2016). 'UN warns Palestinian population will double to 9.5 million by 2050'. The Times of Israel, 21 December 2016, https://www.timesofisrael.com/un-warnspalestinian-population-will-double-to-9-5-million-by-2050/

AMAN (2013). 'Integrity and combating corruption', Sixth Annual Report. April 2014, https://www.aman-palestine.org/data/itemfiles/8614c8ffbbcd9626e02905b6786c0650.pdf

AMAN (2015). 'Integrity and combating corruption', Eighth Annual Report, April 2016, https://www.aman-palestine.org/data/itemfiles/f86f49da1e937975db98fd3e3957822a.pdf

AMAN (2016). 'Integrity and combating corruption', Ninth Annual Report, June 2017, https://www.aman-palestine.org/data/itemfiles/d0a603050d7a903f0bfb3ba368681548.pdf

AMAN (2017). 'Integrity and combating corruption', Tenth Annual Report, June 2017, https://www.aman-palestine.org/data/itemfiles/902b911598cf1e87515378f025379b30.pdf

Arutz Sheva (2017). 'The precise number of Jews in the 'West Bank', June 2017, http://www.israelnationalnews.com/News/News.aspx/213234

Ash-Shami, Um Suhaib (2013). 'Feminist movements in Palestine between الحركات . i https://pulpit.alwatanvoice.com/content/print/313613.html

Awad, Hitrud, Salem, Hilmi S., and Khalilieh, Suhail (2007). '40 Years of the Israeli Occupation of the West Bank and Gaza Strip (1967-2007)', Applied Research InstituteJerusalem (ARIJ), p. 282.

$A Z C$ (2017). 'Palestinian population worldwide by place of residence at the beginning of 2017 (by thousands)', Al-Zaytouna Centre, April 2017, https://eng.alzaytouna.net/2017/04/05/infographic-palestinian-population-worldwide-byplace-of-residence-at-the-beginning-of-2017/

AZC (2018). 'Strategic assessment (104): The plan to liquidate UNRWA: What's next?' Al-Zaytouna Centre, May 2018, https://eng.alzaytouna.net/2018/05/18/strategic-assessment104-the-plan-to-liquidate-unrwa-whats-next/

$B B C$ (2018). 'Khan al-Ahmar: Israel court approves demolition of Bedouin village', September 2018, https://www.bbc.com/news/world-middle-east-45420915

Berger, Yotam (2017). 'How many settlers really live in the West Bank? Haaretz investigation reveals', Haaretz, June 2017, https://www.haaretz.com/israelnews/.premium.MAGAZINE-revealed-how-many-settlers-really-live-in-the-west-bank$\underline{1.5482213}$

CBS (2003). 'Statistical Abstract 2002. The Syrian Arab Republic', http://www.cbssyr.org/eindex.htm

Clarke, Thuston (1981). By Blood \& Fire July 22, 1946: The Attack on the King David Hotel (New York: Putnam Publishing Group).

Courbage, Youssef, Basam, Abu Hamad, and Zagha, Adel (2016). 'Palestine 2030 Demographic Change: Opportunities for Development' UNFPA Palestine, 
http://palestine.unfpa.org/publications/palestine-2030-demographic-change-opportunitiesdevelopment

Daubney, Martin (2015). 'Is feminism destroying the institution of marriage?', The Telegraph, August 2015, https://www.telegraph.co.uk/men/thinking-man/11824814/Isfeminism-destroying-the-institution-of-marriage.html

DoS (2006). 'Jordan in Figures 2005'. May 2006, http://www.dos.gov.jo/dos_home/jorfig/2004/jor_f_e.htm

ESCWA (2017). 'Israeli practices towards the Palestinian people and the question of Apartheid Palestine and the Israeli Occupation', United Nations (UN), Issue No. 1. E/ESCWA/ECRI/2017/1, $\quad$ https://electronicintifada.net/sites/default/files/201703/un_apartheid_report_15_march_english_final_.pdf

EUI, RSCAS, MPC (European University Institute, Robert Schuman Centre for Advanced Studies, Migration Policy Centre) (2013). Migration Facts Palestine. April 2013, http://www.migrationpolicycentre.eu/docs/fact_sheets/Factsheet\%20Palestine.pdf

Fanack (2016). 'The health sector in Palestine', Fanack, October 2016, https://fanack.com/palestine/governance/the-health-sector-in-palestine/

Farrell, Stephen and Sawafta, Ali (2018). 'Palestinians in Jerusalem demolish own homes rather than see Israelis move in', Reuters, July 2018, https://www.reuters.com/article/us-israel-palestinians-demolition/palestinians-in-jerusalemdemolish-own-homes-rather-than-see-israelis-move-in-idUSKBN1K922N

Glass, Charles (2001). 'The Mandate years: Colonialism and the creation of Israel. London Review of Books'. The Guardian, May 2001, https://www.theguardian.com/books/2001/may/31/londonreviewofbooks

Hanafi, Sari (2010). 'Governing Palestinian refugee camps in the Arab East: Governmentalities in search of legitimacy', Policy and Governance in Palestinian Refugee Camps. Working Paper Series \#1, (Beirut: AUB), October 2010, http://website.aub.edu.lb/ifi/public_policy/pal_camps/Documents/working_papers_series/201 01206ifi_pc_wps01_sari_hanafi_english.pdf

Hoffman, Bruce (1985). 'Jewish Terrorist Activities and the British Government in Palestine, 1939-1947', Ph.D. Dissertation, (Oxford: St. Antony's College), p. 391, https://ora.ox.ac.uk/catalog/uuid:762b3fb7-837a-4d21-ac2b-

$44676535 \mathrm{ffa} /$ /download file?file format $=$ pdf\&safe filename $=602328526$.pdf\&type of _wor $\mathrm{k}=$ Thesis

ICBS (2005). 'Statistical Abstract of Israel', No. 56. Jerusalem, 2005. http://webcache.googleusercontent.com/search?q=cache:iRR2cyR9oy0J:https://www.cbs.gov. il/en/publications/Pages/2005/Statistical-Abstract-of-Israel-2005-No-

56. $\operatorname{aspx} \& \mathrm{hl}=\mathrm{en} \& \mathrm{gl}=\mathrm{ps} \&$ strip $=1 \& \mathrm{vwsrc}=0$

IIAO (2017). 'Online Document: List of international law violations by the state of Israel', http://itisapartheid.org/Documents_pdf_etc/IsraelViolationsInternationalLaw.pdf

ILO (2018). 'The Occupied Palestinian Territory: An Employment Diagnostic Study', Regional Office for Arab States, ILO, United Nations, The Question of Palestine, Geneva, Switzerland. https://www.un.org/unispal/document/the-occupied-palestinian-territory-an-iloemployment-diagnostic-study/

Isaac, Jad, Hilal, Jane, Bannourah, Enas, Sahouri, Nadine, Abu Mohor, Elias, and Rishmawi, Khaldoun (2015). 'The Segregation Wall impacts on Palestinian environment'. 
Applied Research Institute - Jerusalem (ARIJ), Bethlehem, West Bank, Palestine, https://www.arij.org/files/arijadmin/2016/The_Segregation_Wall_impacts_on_Palestinian_En vironment.pdf

Jaber, Firas and Zuhour, Kifah (2018). 'Palestine under occupation. Is the 2030 Agenda for development possible? Social and Economic Policies Monitor', Almarsad, May 2018, http://www.almarsad.ps/wp-content/uploads/2018/09/Palestine-under-Occuption-Is-Agenda2030-for-Development-possible-PDF-English.pdf

JVL (2018). 'Vital Statistics: Latest Population Statistics for Israel', April 2018, http://www.jewishvirtuallibrary.org/latest-population-statistics-for-israel

Lazaroff, Tovah (2018). 'Europe warns: Razing Bedouin village Khan Al-Ahmar is a war crime. The parliamentarians said they condemned any unilateral decision or action that may undermine the prospects of this solution', The Jerusalem Post, September 2018, https://www.jpost.com/Israel-News/Politics-And-Diplomacy/European-Parliament-demandscompensation-from-Israel-for-Khan-al-Ahmar-567140

$M A$ 'AN (2017). 'Palestinian demolishes own home in Jerusalem to avoid Israeli fines', November 2017, https://www.maannews.com/Content.aspx?id=779470

$M A S$ (2015). 'Training provision and employment in Palestine: Gaza, East Jerusalem, Refugee Camps, Area C; Jerusalem and Ramallah, Palestine. A study funded by GIZ', http://www.mas.ps/files/server/20151711140259-1.pdf

Masalha, Nur (1992). 'Expulsion of the Palestinians - The Concept of "Transfer" in Zionist Political Thought 1882-1948', (Washington DC: Institute of Palestinian Studies), https://www.foreignaffairs.com/reviews/capsule-review/1993-06-01/expulsion-palestiniansconcept-transfer-zionist-political-thought

Machover, Moshe (2018). 'An immoral dilemma: The trap of Zionist propaganda', Journal of Palestine Studies 47 (4), pp. 69-78.

Massad, Salwa G., Shaheen, Mohammed, Karam, Rita, Brown, Ryan, Glick, Peter, Linnemay, Sebastian, and Khammash, Umaiyeh (2016). 'Substance use among Palestinian youth in the West Bank, Palestine: A qualitative investigation'. BMC Public Health (16), Article No. 800, https://doi.org/10.1186/s12889-016-3472-4

Mayamey, Babak (2010). 'Zionism: A Critical Account 1897-1948. The Development of Israel and the Exodus of Palestine from A New Historian' Perspective', POLIS Journal (4), pp. 1-34.

McQueeney, Kerry (2017). 'Hydro: The drug epidemic sweeping through the West Bank', The National, July 2017, https://www.thenational.ae/world/mena/hydro-the-drugepidemic-sweeping-through-the-west-bank-1.610097

Mcardle, Mairead (2018). 'Palestinian families destroy their homes to avoid seeing Israelis move in', National Review, July 2018, https://www.nationalreview.com/news/palestinians-destroy-homes-avoid-israelis-move-in/

MEM (2017). 'Gaza poverty blamed for fall in marriages and increase in divorce rate'. January 2017, https://www.middleeastmonitor.com/20170130-gaza-poverty-blamed-for-fallin-marriages-and-increase-in-divorce-rate/

Mills, Eric (1932). 'Census of Palestine 1931. Population of villages, towns and administrative areas', https://archive.org/details/CensusOfPalestine1931.PopulationOfVillagesTownsAndAdministr $\underline{\text { ativeAreas }}$ 
MoEHE (2006). 'Education Statistical Yearbook 2005/2006', Ramallah, Palestine.

MoEHE (2014). 'Education Statistics', http://www.mohe.gov.ps/ShowArticle.aspx?ID=335

MoH (2006). 'Health Status in Palestine - Annual Report 2005', Gaza, Palestine, August 2006.

Nazaal, Nasouh (2012). 'Divorce rate high in Palestinian Territories. Big number of 'Khole' cases are filed at 'Sharia' Courts', Gulf News, December 2012, https://gulfnews.com/news/mena/palestine/divorce-rate-high-in-palestinian-territories$\underline{1.1123161}$

Nazaal, Nasouh (2014). 'Divorce rate soars for Palestinian newly-weds. Religious figures in the West Bank agree that social media addiction has been a key reason for the increase in divorce cases', Gulf News, March 2014, https://gulfnews.com/news/mena/palestine/divorce-rate-soars-for-palestinian-newly-weds$\underline{1.1303755}$

Neff, Donald (1995). 'Jewish terrorists assassinate U.N. Peacekeeper Count Folke Bernadotte', Washington Report on Middle East Affairs, September 1995, https://www.wrmea.org/1995-september/jewish-terrorists-assassinate-u.n.-peacekeeper-countfolke-bernadotte.html

NGO Monitor (2020). 'Making NGOs Accountable. Palestinian NGO Network (PNGO)', Updated: January 2020; Accessed: September 2020, https://www.ngomonitor.org/ngos/palestinian_ngo_network_pngo_/

Pappé, Ilan (1992). The Making of the Arab-Israeli Conflict 1947-1951 (New York: St. Martin's Press).

Pappé, Ilan (2006a). The Ethnic Cleansing of Palestine (Oxford: Oneworld).

Pappé, Ilan (2006b). The 1948 Ethnic Cleansing of Palestine. Journal of Palestine

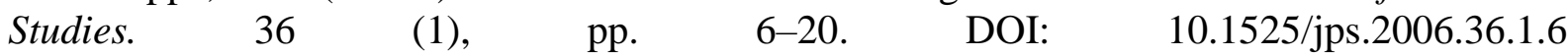
https://www.jstor.org/stable/10.1525/jps.2006.36.1.6?seq=1 and https://www.jstor.org/stable/10.1525/jps.2006.36.1.6

Pappé, Ilan (2018). 'Israel's new law is a form of apartheid', The Hindu, July 2018, https://www.thehindu.com/opinion/op-ed/israels-new-law-is-a-form-ofapartheid/article24513993.ece

PCBS (1999). 'Population, housing and establishment census-1997. Final ResultPalestinian Territory', Ramallah, Palestine.

PCBS (2004). 'Health Services Survey-2003', Ramallah, Palestine. http://www.pcbs.gov.ps/DesktopDefault.aspx?tabID=4003\&lang=en

PCBS (2005a). 'Statistical Abstract of Palestine', No. 6. Ramallah, Palestine, November 2005.

PCBS (2005b). 'Housing and housing conditions-Annual Report', Ramallah, Palestine, http://www.pcbs.gov.ps/DesktopDefault.aspx?tabID=3665\&lang=en

PCBS (2005c). 'The Millennium Development Goals in Palestine Concepts and Trends', Ramallah, Palestine, June 2005.

PCBS (2005d). 'Dissemination and analysis of census findings. In-depth analysis study series (11). Changes of the Palestinian labor market indicators during the Al Aqsa Intifada', 
Ramallah-Palestine,

http://webcache.googleusercontent.com/search?q=cache:TF2oCCVNO0oJ:www.pcbs.gov.ps/ Downloads/book1168.pdf $+\& \mathrm{~cd}=1 \& \mathrm{hl}=\mathrm{en} \& \mathrm{ct}=\mathrm{clnk} \& \mathrm{gl}=\mathrm{ps}$

PCBS (2005e). 'Education-Time Series Statistics', Ramallah, Palestine, 2005, http://www.pcbs.gov.ps/DesktopDefault.aspx?tabID=3777\&lang=en

PCBS (2005f). 'Demography and health survey 2004', Ramallah, Palestine, June 2005, http://www.pcbs.gov.ps/pcbs-metadata-en-v4.3/index.php/catalog/471/accesspolicy

PCBS (2006a). 'Palestine in Figures-2005', Ramallah, Palestine.

PCBS (2006b). 'Demography Statistics-Population Projection', Ramallah, Palestine, July 2006, http://www.pcbs.gov.ps/DesktopDefault.aspx?tabID=3845\&lang=en

PCBS (2007). 'Demographic and Socioeconomic Status of the Palestinian People at the end of 2006', Ramallah, Palestine, December 2006, http://webcache.googleusercontent.com/search?q=cache:WcnvffXgW3QJ:www.pcbs.gov.ps/ Portals/_pcbs/PressRelease/endyear2006_E.pdf $+\& c d=1 \& h l=e n \& c t=c \operatorname{lnk} \& g l=p s$

PCBS (2010). 'Palestine in Figures 2009 - May 2010', Ramallah, Palestine, http://webcache.googleusercontent.com/search?q=cache:F8qLxyDjFa4J:www.pcbs.gov.ps/Po rtals/_PCBS/Downloads/book1661.pdf $+\& \mathrm{~cd}=7 \& \mathrm{hl}=\mathrm{en} \& \mathrm{ct}=\mathrm{clnk} \& \mathrm{gl}=\mathrm{ps}$

PCBS (2011). 'Palestine - Migration Survey in the Palestinian Territory', 2010, Ramallah, Palestine, http://www.pcbs.gov.ps/PCBS-Metadata-en-v4.3/index.php/catalog/112

PCBS (2016a). 'On the $68^{\text {th }}$ Anniversary of the Palestinian Nakba', May 2016, http://www.pcbs.gov.ps/site/512/default.aspx?tabID=512\&lang=en \&ItemID=1661\&mid=317 $\underline{2 \& \text { wversion}=\text { Staging }}$

PCBS (2016b). 'Palestinians at the End of 2016', www.lacs.ps/documentsShow.aspx?ATT_ID=30133

PCBS (2016c). 'Crude marriage rate in Palestine by governorate (1997-2016)', http://www.pcbs.gov.ps/Portals/_Rainbow/Documents/VS-2016-03e.htm

PCBS (2016d). 'Crude divorce rate in Palestine by governorate (1997-2016)', http://www.pcbs.gov.ps/Portals/_Rainbow/Documents/VS-2016-07e.htm

PCBS (2017a). 'The International Population Day 11/07/2017. Palestinian Central Bureau of Statistics and National Population Committee', http://www.pcbs.gov.ps/post.aspx?lang=en\&ItemID=1975

PCBS (2017b). 'Poverty Profile in Palestine 2017', http://www.pcbs.gov.ps/Document/pdf/txte_poverty2017.pdf?date=16_4_2018_2

PCBS (2017c). 'Number of schools by region, stage and school gender, 2016/2017', http://www.pcbs.gov.ps/Portals/_Rainbow/Documents/Education2016-01E.htm

PCBS (2017d). 'Number of students in schools and kindergartens by region and supervising authority, 1994/1995-2016/2017', http://www.pcbs.gov.ps/Portals/_Rainbow/Documents/Education-1994-2016-02E.htm

PCBS (2018). 'Palestine in Figures-2017', March 2018, http://www.pcbs.gov.ps/Downloads/book2362.pdf

PNIPH (2017). 'Illicit Drug Use in Palestine: A Qualitative Investigation. A formative Phase Study Report', Palestinian Ministry of Health, United Nations Office on Drugs and Crime (UNODC), Korea International Cooperation Agency (KOICA), and World Health 
Organization

https://www.unodc.org/documents/publications/Illicit_Drug_Use_in_Palestine.pdf

(WHO),

Provéndol, Juan I (2012). 'En medio de la tensión, un recorrido por las murallas entre Israel y Palestina', Palestinalibre.Org., $\quad$ November 2012, http://www.palestinalibre.org/articulo.php?a=42341

Ramahi, Hanan (2015). 'Education in Palestine: Current Challenges and Emancipatory Alternatives', Rosa Luxemburg Stiftung Regional Office Palestine, http://www.rosaluxemburg.ps/wp-content/uploads/2015/11/RLS-Study-29.11.15-final.pdf

Ramahi, Sawsan (2013). 'Corruption in the Palestinian Authority. A Special Issue', Middle East Monitor, December 2013, https://www.amanpalestine.org/data/itemfiles/b2a7e241322895ba53fdd6425a55c40a.pdf

RecoNow (2016). 'The Higher Education System in Palestine', National Report, May 2016, http://www.reconow.eu/files/fileusers/5140_National-Report-Palestine-RecoNOW.pdf

Salem, Hilmi S., Hilal, Jane, Ghattas, Roubina (eds.). (2007). 'Status of the Environment in the Occupied Palestinian Territories', Applied Research Institute-Jerusalem (ARIJ), Bethlehem, Palestine, p. 255.

Salem, Hilmi S. (2009). 'The situation in the Occupied Palestinian Territories: Terrorism or resistance and its consequences', A paper presented at the $10^{\text {th }}$ Mediterranean Research Meeting, Workshop 2, Transitional Justice: A Solution against Terrorism in Occupied Territories. Florence and Montecatini Terme, Italy, 25-28 March 2009, http://cadmus.eui.eu/bitstream/handle/1814/12177/RSCAS_DL\%202009_02.pdf;sequence=1

Salem, Hilmi S. (2011) 'Social, environmental and security impacts of climate change on the Eastern Mediterranean', in: Brauch, Hans G., Úrsula Spring, Oswald , Mesjasz, Czeslaw, Grin, John, Kameri-Mbote, Patricia, Chourou, Béchir, Dunay, Pal, and Birkmann, Jörn, (eds.): Coping with Global Environmental Change, Disasters and Security. Threats, Challenges, Vulnerabilities and Risks (New York: Springer), pp. 421-445.

Salem, Hilmi S. (2018). 'A great potential for solar energy investment in Palestine', A presentation given at the International DAAD (German Academic Exchange Service) Alumni Seminar: Intensifying the Diffusion of Solar Photovoltaic Technology in Developing Countries for Improving Energy Access in Rural Areas, Cottbus, Germany 12-19 June 2018, https://www.b-tu.de/fg-umweltrecht/projekte/daad/2018

Salem, Hilmi S. (2019a). 'No sustainable development in the lack of environmental justice', Environmental Justice, 12 (3): pp. 140-157. DOI: 10.1089/env.2018.0040 https://www.liebertpub.com/doi/10.1089/env.2018.0040

Salem, Hilmi S. (2019b). 'The necessity of rural electrification in the Occupied Palestinian Territories: Status, challenges, and opportunities, with the case study of the Jubbet Ad-Dib village, Bethlehem Governorate', Journal of Nature Science and Sustainable Technology. 13(2): pp. 99-131. http://www.novapublishers.org/catalog/product_info.php?products_id=65999

Salem, Hilmi S. (2020). 'Digitization of the health and education sectors in the Palestinian society, in view of the United Nations Sustainable Development Goals', in: Brauweiler, Hans-Christian., Kurchenkov, Vladimir V., Abilov, Serik, and Zirkler, Bernd (eds.): Digitalization and Industry 4.0: Economic and Societal Development - An International and Interdisciplinary Exchange of Views and Ideas, pp: 53-89. DOI: 
10.1007/978-3-658-27110-7. ISBN 978-3-658-27110-7. Wiesbaden: Springer Gabler, Germany. https://www.springer.com/gp/book/9783658271091

Shalom, Oded and Ben Kimon, Elisha (2016). 'The movement to return to Gaza's Gush Katif', Ynet Magazine, August 2016, https://www.ynetnews.com/articles/0,7340,L$\underline{4839896,00 . h t m l}$

Shimoni, Gideon (1980). Jews and Zionism: The South African Experience 1910-1967 (Oxford: Oxford University Press).

The HyperTexts (2010). 'Jewish intellectuals who have opposed Zionism and/or Israeli racism, injustices, occupation, Apartheid and/or ethnic cleansing', Accessed: September 2020, http://www.thehypertexts.com/Jewish\%20Intellectuals\%20Who\%20Opposed\%20Zionism\%2 0Israel\%20Racism\%20Injustices\%20Apartheid\%20Ethnic\%20Cleansing.htm

The World Bank (2008). 'West Bank and Gaza. The economic effects of restricted access to land in the West Bank', Accessed: September 2020, http://documents.worldbank.org/curated/en/654801468176641469/pdf/473230WP0GZ0Re10 1PUBLIC10Box334128B.pdf

TTOI (2018). 'European countries blast US embassy move to Jerusalem. Turkey calls relocation 'legally null and void'; Ireland says it 'inflames a very tense situation'; Netherlands terms it 'unwise', 14 May 2018, https://www.timesofisrael.com/european-countries-blast-usembassy-move-to-jerusalem/

TWIP (2015). 'Special Issue: Area C. November 2015. Co-sponsored by the United Nations Human Settlements Programme (UN-Habitat), and the UNDP's Programme of Assistance to the Palestinian People (UNDP/PAPP)', November 2015, http://thisweekinpalestine.com/wp-content/uploads/2015/10/Special-Issue-Area-C.pdf

Underwood, Alexia (2018). 'The US plans to end all support for UN agency that aids Palestinian refugees. The organization provides food, education, and health care for nearly 5 million refugees', Vox, August 2018, https://www.vox.com/2018/8/31/17804262/palestinianrefugees-unrwa-funding-cut

UN (2004). 'The Question of Palestine: ICJ Advisory Opinion on the Legal Consequences of the Construction of a Wall in the OPT - Full text', Advisory Opinion of the International Court of Justice on the Legal Consequences of the Construction of a Wall in the Occupied Palestinian Territory. International Court of Justice, The Hague, The Netherlands, July 9, 2004, https://www.un.org/unispal/document/auto-insert-178825/

UNDP (2004). 'Socio-economic indicators-Lebanon', Accessed: September 2020, http://www.undp.org.lb/information/socioecostatistics.html

UNDP (2006). 'Human Development Report-2006', January 2006, http://hdr.undp.org/sites/default/files/reports/267/hdr06-complete.pdf

UNDP (2015). 'Human Development Report- 2015', January 2015, http://hdr.undp.org/sites/default/files/2015 human_development_report.pdf

UN News (2016). 'Population growth in occupied Palestinian territory to drive demand for housing, services', December 2016, https://news.un.org/en/story/2016/12/548332population-growth-occupied-palestinian-territory-drive-demand-housing-services

UNRWA (1950) 'Resolution 194', https://www.unrwa.org/content/resolution-194 and https://www.unrwa.org/who-we-are?tid=85 
UNRWA (2010). 'West Bank and Gaza Strip Population Census of 2007', Briefing Paper, January 2010, https://www.unrwa.org/userfiles/2010012035949.pdf

UNRWA (2016a). 'Where we work [West Bank]', December 2016, https://www.unrwa.org/where-we-work/west-bank

UNRWA (2016b). 'Where we work [Gaza Strip]', December 2016, https://www.unrwa.org/where-we-work/gaza-strip

US Census Bureau (2005). 'American Community Survey 2004', http://factfinder.census.gov/servlet/GRTTable? bm=y\&-_box_head_nbr=R0105\&$\underline{\text { ds_name }=\text { ACS_2004_EST_G00_\&-format=US-30 }}$

Vick, Karl (2014). 'Pope makes surprise stop to pray at Bethlehem Separation Wall', Time, May 2014, http://time.com/113866/pope-bethlehem-israel-abbas/

White, Ben (2017). 'UN Report: Israel has established an 'Apartheid Regime'. Report breaks new ground on the UN's examination of the situation in occupied Palestine by using the 'Aord Apartheid.', Aljazeera, March 2017, https://www.aljazeera.com/indepth/features/2017/03/report-israel-established-apartheidregime-170315054053798.html

WHO (2018). 'WHO concerned over increasingly overwhelmed health services in the Gaza Strip', April 2018, http://www.emro.who.int/palestine-press-releases/2018/whoconcerned-over-increasingly-overwhelmed-health-services-in-the-gaza-strip-april-2018.html

Wikipedia (2011). 'File: Occupied Palestinian Territories.jpg', Accessed: September 2020, https://commons.wikimedia.org/wiki/File:Occupied_Palestinian_Territories.jpg

Wikipedia (2014). 'File: Palestinian-loss-of-land-1946-2010.jpg', Accessed: September 2020, https://en.wikipedia.org/wiki/File:Palestinian-loss-of-land-1946-2010.jpg

Wikipedia (2020a). 'Palestinian Right of Return', Accessed: September 2020, https://en.wikipedia.org/wiki/Palestinian_right_of_return

Wikipedia (2020b). 'West Bank Areas in the Oslo II Accord', Accessed: September 2020, https://en.wikipedia.org/wiki/West_Bank_Areas_in_the_Oslo_II_Accord

Wikipedia (2020c). 'Palestinian Refugee Camps', Accessed: September 2020, https://en.wikipedia.org/wiki/Palestinian_refugees

Wikipedia (2020d). 'Khan al-Ahmar', Accessed: September 2020, https://en.wikipedia.org/wiki/Khan_al-Ahmar\#cite_note-12

Wikipedia (2020e). 'Fourth Geneva Convention', Accessed: September 2020, https://en.wikipedia.org/wiki/Fourth_Geneva_Convention

Wikipedia (2020f). 'Education in the Palestinian territories', Accessed: September 2020, https://en.wikipedia.org/wiki/List_of_universities_and_colleges_in_the_Palestinian_Territorie $\underline{\mathrm{S}}$

Williams, Jennifer and Zarracina, Javier (2016). 'The growth of Israeli settlements, $\begin{array}{lllll}\text { explained in } 5 \text { charts', Vox, 2016, } & \text { December }\end{array}$ https://www.vox.com/world/2016/12/30/14088842/israeli-settlements-explained-in-5-charts

Worldometers (2020). 'State of Palestine Population (LIVE): 5,132,172', Accessed: September 2020, $\quad$ http://www.worldometers.info/world-population/state-of-palestinepopulation/ 
WPR (2020). 'Palestine Population 2020', Accessed: September 2020, http://worldpopulationreview.com/countries/palestine-population/ Service).

Zayid, Ismail (1980). Zionism the Myth and the Reality (Indianapolis: Islamic Book

Zayid, Ismail (2002a). 'Palestine: Fifty years of ethnic cleansing and dispossession. Dossier on Palestine', Shunpiking Magazine, May 2018, pp. 4-7, https://tonyseed.wordpress.com/2018/05/15/about-the-balfour-declaration/\#more-25637

Zayid, Ismail (2002b). 'Israeli Terrorism. How you define a terrorist act depends on whether you're looking down the wrong end of a gun barrel', Shunpiking Magazine, October 2002, pp. 18-19, https://tonyseed.wordpress.com/2002/10/28/dossier-on-palestine\%E2\%80\%93-contents/
Zayid, Ismail (2006). 'Document: A short history of Israeli State terrorism', The Globe and Mail, February 2006, https://wikispooks.com/wiki/Document:A_Short_History_of_Israeli_State_Terrorism

Zonszein, Mariav (2014). 'Walled off: 12 years of Israel's separation barrier. An international photography collective documents the evolution and conflicts surrounding the barrier wall', Aljazeera America, March 2014, Accessed: September 2020, http://america.aljazeera.com/articles/2014/3/12/visual-activismactivestillsphotographsthebarrierwall.html

\section{Acknowledgements}

The Author wishes to extend his special and sincere thanks to Ms. Julia Frankosky, Government Information and Political Science Library, Michigan State University, East Lansing, Michigan, USA, for her critical review of this article. Also, special thanks are extended to friends and colleagues for their review of the article. Moreover, special and sincere thanks are extended to the Reviewers (anonymous) and Dr. Oguzhan Goksel, Editorin-Chief of the New Middle Eastern Studies (NMES) journal, for their critical review and outstanding comments which have added a great value to the article.

\section{About the Author}

Hilmi S. Salem is a multidisciplinary research scientist, professional engineer, academician, educator, consultant, and global expert, who has been involved in projects on water, energy, the environment, biodiversity, climate change, sustainable development, United Nations' Sustainable Development Goals (UN SDGs), geopolitics, and other areas as well. After he obtained his Doctorate degree from the Christian-Albrechts Universitaet (CAU) zu Kiel, Kiel, Germany, through a DAAD scholarship, Prof. Dr. Salem has worked at, and contributed to, academic, industrial, governmental, and nongovernmental institutions in the Middle East, North Africa, East Africa, and West Asia regions, Europe (Germany, Belgium, Italy, Switzerland, UK, and others), Canada, the USA, and Australia, as well as to United Nations' (UN) organizations, such as UNEP, UNDP, UNESCO, and WHO. Prof. Salem has authored and co-authored over 170 publications, including papers published in internationally peer- 
reviewed journals, papers presented at international conferences, technical reports, books, chapters in books, atlases, and policy- and strategy-position papers. His published work has been relied on, cited, and referenced by thousands of research scientists, including graduate students in more than 120 distinguished universities, worldwide. Prof. Salem has also led large teams of research scientists, professional engineers, managers, and administrators, with respect to scientific, technical, managerial, personnel, financial, and institutional issues, as well as to research projects and programs at academic, industrial, governmental, and nongovernmental institutions in the scientific fields and geographic areas mentioned above. Prof. Salem was also asked, by international institutions and organizations, to evaluate research projects valued millions of US Dollars. Prof. Salem was honoured, by international organizations, some prestigious awards on his contributions to the international scientific community in the fields of natural sciences, engineering, and humanities (socioeconomics, politics, geopolitics, human rights, and environmental justice.) 